\title{
Plasmonic photocatalysis applied to solar fuels
}

\author{
Steven Bardey, ${ }^{\text {ab }}$ Audrey Bonduelle-Skrzypczak, ${ }^{\mathrm{b}}$ \\ Antoine Fecant, (1D ${ }^{\mathrm{b}}$ Zhenpeng Cui, ${ }^{\mathrm{c}}$ Christophe Colbeau-Justin, ${ }^{\mathrm{C}}$ \\ Valerie Caps $\mathbb{B D}^{* a}$ and Valerie Keller ${ }^{a}$
}

Received 2nd October 2018, Accepted 16th November 2018

DOI: $10.1039 / \mathrm{c} 8 \mathrm{fd} 00144 \mathrm{~h}$

The induction of chemical processes by plasmonic systems is a rapidly growing field with potentially many strategic applications. One of them is the transformation of solar energy into chemical fuel by the association of plasmonic metal nanoparticles (M NPs) and a semi-conductor (SC). When the localized surface plasmon resonance (LSPR) and the SC absorption do not match, one limitation of these systems is the efficiency of hot electron transfer from M NPs to SC through the Schottky barrier formed at the M NP/SC interfaces. Here we show that high surface area $1 \mathrm{wt} \% \mathrm{Au} / \mathrm{TiO}_{2-\mathrm{Uv} 100}$, prepared by adsorption of a $\mathrm{NaBH}_{4}$-protected $3 \mathrm{~nm}$ gold sol, readily catalyzes the photoreduction of carbon dioxide with water into methane under both solar and visible-only irradiation with a $\mathrm{CH}_{4}$ vs. $\mathrm{H}_{2}$ selectivity of $63 \%$. Tuning Au NP size and titania surface area, in particular via thermal treatments, highlights the key role of the metal dispersion and of the accessible $\mathrm{Au}-\mathrm{TiO}_{2}$ perimeter interface on the direct SC-based solar process. The impact of Au NPdensity in turn provides evidence for the dual role of gold as co-catalyst and recombination sites for charge carriers. It is shown that the plasmon-induced process contributes up to $20 \%$ of the solar activity. The plasmon-based contribution is enhanced by a large Au NP size and a high degree of crystallinity of the SC support. By minimizing surface hydroxylation while retaining a relatively high surface area of $120 \mathrm{~m}^{2} \mathrm{~g}^{-1}$, pre-calcining $\mathrm{TiO}_{2-\mathrm{Uv} 100}$ at $450{ }^{\circ} \mathrm{C}$ leads to an optimum monometallic system in terms of activity and selectivity under both solar and visible irradiation. A state-of-the-art methane selectivity of $100 \%$ is achieved in the hot electron process.

\section{Introduction}

The direct conversion of solar energy into valuable chemical fuels is a great challengeforclean energy production. In this context, the photo-reduction of $\mathrm{CO}_{2}$

Institut de Chimie et des Procédés pour l'Energie, l'Environnement et la Santé (ICPEES), UMR7515, 25 rue Becquerel, 67087 Strasbourg, France.E-mail: caps@unistra.fr

${ }^{b} I F P$ Energies Nouvelles (IFPEN), Rond-point de l'échangeur de Solaize, 69360 Solaize, France

'Laboratoire de Chimie Physique, CNRS UMR 8000, Univ. Paris-Sud, Université Paris-Saclay, 91405 Orsay, France 
into methane and methanol has received increasing attention over the last few years. ${ }^{1-3}$ This way of producing synthetic fuels would indeed represent a step forward towards sustainability, due to the nature of the carbon source, a major byproduct of energy consumption, and its increasing availability. However, the conversion rate of photonic energy into chemical energy by semi-conductor-based photocatalysts is still too low, as current energy carriers suffer from a short lifetime (fast recombination) and use only a fraction of the solar spectrum. Hence, the development of photocatalytic materials with improved and broadened light absorption is needed in order to efficiently use sunlight as a primary energy source. Amongst the possible materials, multi-component systems containing metal nanoparticles (M NPs) interacting with a semi-conductor (SC) appear promising. ${ }^{4,5}$ In addition to their beneftcial role as co-catalyst and electron traps ${ }^{6,7}$ MNPs with plasmonic properties ${ }^{8}$ mayindeed improve the photocatalytic performances of the semi-conductor by plasmon-derived physical phenomena, including hot electron generation ${ }^{8}$ and utilization. ${ }^{9-13}$ Hot electron injection into the SC conduction band is however dependent on the Schottky barrier formed at themetal-supportinterface ${ }^{14,15}$ and littleis knownabout thenanostructuration of the optimum interaction. Energy transfer from the plasmonic NP to the SC remains low, ${ }^{16}$ although efficient hot electron transfer by plasmon-induced interfacial charge transfer has been reported for cadmium selenide nanorods with gold tips, ${ }^{17}$ highlighting the importance of atomic description of the interface ${ }^{18}$ The interface in general has been found to play a key role in many catalytic processes. ${ }^{19,20}$ More structure-activity relationships are thus needed, which implies a precise control of the M-SC interface at the nanoscale. We have recently designed an optimized heterojunction between titania and carbon nitride with improved activity for hydrogen production from water. ${ }^{21}$ Here we show theimpact of the interface nanostructuration of gold-titania composites, in terms of accessibility of $\mathrm{Au}-\mathrm{TiO}_{2}$ dual perimeter sites, $\mathrm{Au}$ NP size and density, and titania surface functionalization and crystallinity, on their compared performances in solar and visible photocatalytic gas phase reduction of $\mathrm{CO}_{2}$ in an optimized swept ftxed-bed reactor.

\section{Results and discussion}

Under artiftcial solar conditions (see Experimental section), both methane and hydrogen are produced. No other products are detected, which is commonly observed in the gas phase process using water as a reductant. ${ }^{22}$ Fig. 1 shows the typical evolution of methane and hydrogen as a function of time. As can be seen, the production rates of both methane and hydrogen increase in the ftrst 60 to 90 minutes of reaction, at which point they reach a maximum. A decrease in methane and hydrogen production rates is then observed in the next 8.5-9h of reaction until a plateau is reached. The following discussion will be based on average production rates, using the average of all 45 production rates monitored during the $10 \mathrm{~h}$ reaction (one every $14 \mathrm{~min}$ ). In our set-up, pure anatase $\mathrm{TiO}_{2}$ UV100 readily produces $1 \mathrm{mmol} \mathrm{h}^{-1} \mathrm{~g}^{-1}$ of methane on average under solar irradiation. This low yet signiftcant activity obtained without metal deposition can be attributed to oxygen vacancies present on anatase crystallites ${ }^{23-26}$ and to the low yet signiftcant amount of UV irradiation present in the artiftcial solar spectrum (1\%, see Experimental section), capable of efficiently activating anatase $\mathrm{TiO}_{2}$. 


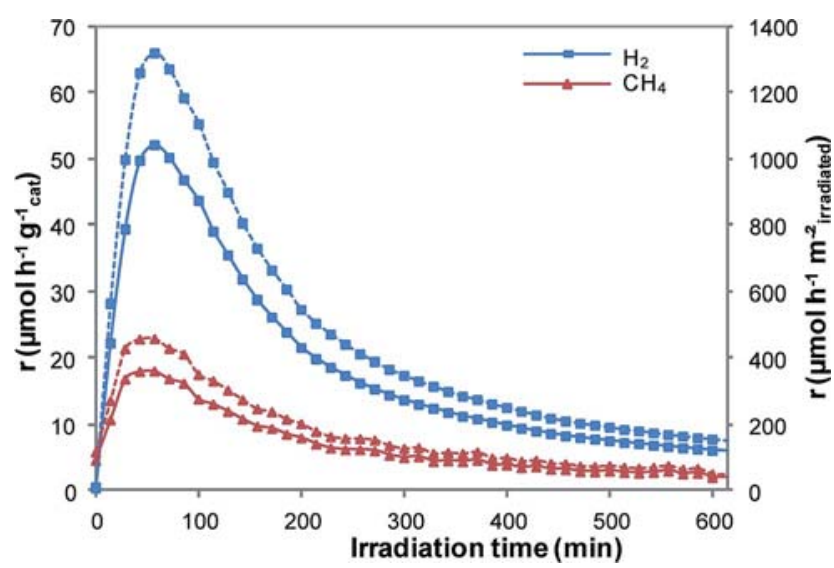

Fig. $1 \mathrm{H}_{2}(-)$ and $\mathrm{CH}_{4}($ ( ) ) photocatalytic production rates per irradiated surface (dashed lines, right $Y$ axis) and per gram (continuous lines, left axis) versus solar irradiation time for $\mathrm{Au}_{3 \mathrm{~nm}} / \mathrm{TiO}_{2}$.

Oxygen vacancies are proposed to activate the particularly inert and stable $\mathrm{CO}_{2}$ molecule by allowing $\mathrm{CO}_{2}$ adsorption on the titania surface. Subsequent reduction of adsorbed $\mathrm{CO}_{2}$ to $\mathrm{CH}_{4}$ involves the in situ formation of the active $\mathrm{H}^{\circ}$ reducingagent, ftrst bywater oxidation on UV-generated holes, then by reduction of the resulting protons with UV-generated electrons, following the net reaction

$$
\mathrm{CO}_{2}+8 \mathrm{H}^{+}+8 \mathrm{e}^{-} / \mathrm{CH}_{4}+2 \mathrm{H}_{2} \mathrm{O}
$$

Straight-forward addition of gold nanoparticles ( $1 \mathrm{wt} \%, 3 \mathrm{~nm})$, using colloidal deposition on the high surface area semi-conductor ${ }^{27}$ results in a major increase in the average solar production rate to $7.1 \mathrm{mmol} \mathrm{h}^{-1} \mathrm{~g}^{-1}$, i.e. $159 \mathrm{~mL} \mathrm{~h}^{-1} \mathrm{~g}^{-1}$. In addition, the selectivity of the process towards $\mathrm{CH}_{4} v s . \mathrm{H}_{2}$ formation signiftcantly increases from $45 \%$ to $60 \%$ (Fig. 2 b). The starting gold-based composite thus exhibits close performance to a standard established in the literature in 2009 (160 $\left.\mathrm{mL} \mathrm{h}^{-1} \mathrm{~g}^{-1}\right)^{28}$ and a high selectivity to methane, as compared with other monometallic $\mathrm{Au} / \mathrm{TiO}_{2}$ photocatalysts. ${ }^{4}$ By acting as electron traps, Au NPs are known to enhance charge separation, i.e. decrease recombination occurrences, increase lifetimes of charge carriers and enhance in situ formation of reducing species. Au NPs arealsowell-known toactas co-catalysts. ${ }^{6}$ In addition, the presence of Au NPs on the titania surface is known to create oxygen vacancies at the perimeter interface, which could facilitate $\mathrm{CO}_{2}$ activation.

\section{Post-calcination effect}

Calcining this $\mathrm{Au} 3 \mathrm{~nm} / \mathrm{TiO}_{2}$ composite in air results in a signiftcant decrease in methane and hydrogen solar production rates with increasing calcination temperature, until no product at all is detected when calcination is performed at $900^{\circ} \mathrm{C}$ (Fig. 2a). Calcination actually causes a major loss of overall surface area, accompanied with a decrease in pore volume and modiftcation of the mean pore diameters (Fig. 3). 

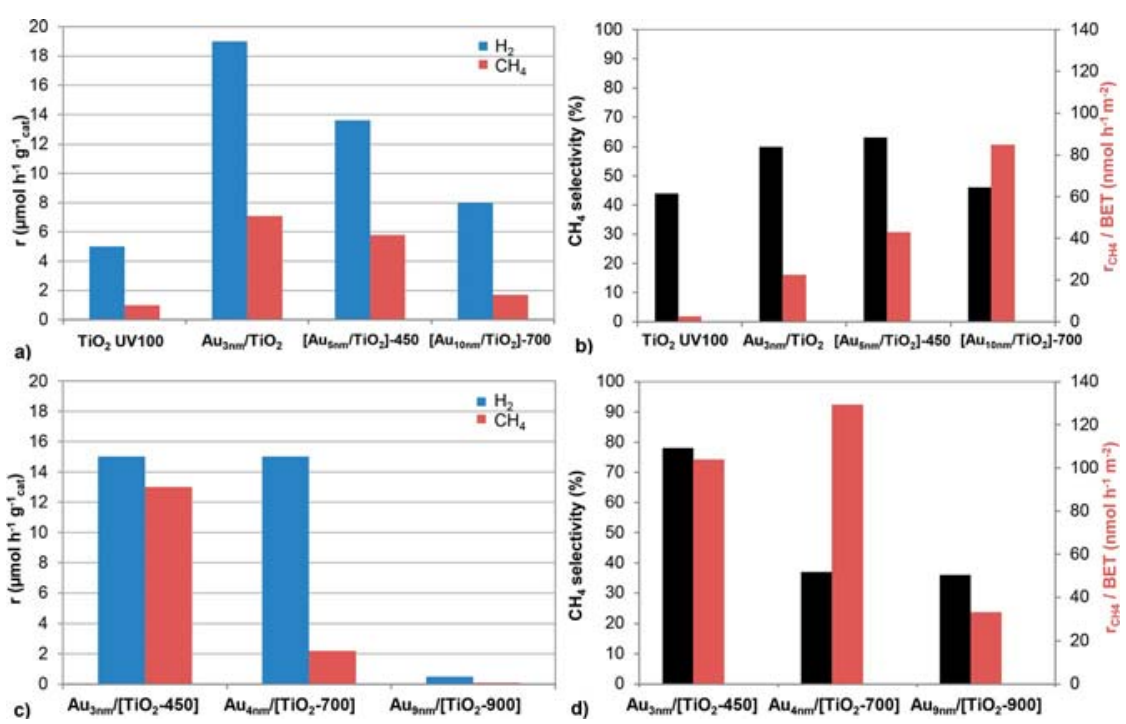

Fig. 2 (a) $\mathrm{H}_{2}$ and $\mathrm{CH}_{4}$ production rates for $\mathrm{TiO}_{2}, \mathrm{Au}_{3 \mathrm{~nm}} / \mathrm{TiO}_{2}$ and post-calcined $\mathrm{Au} / \mathrm{TiO}_{2}$ composites. The $\left[\mathrm{Au}_{43 \mathrm{~nm}} / \mathrm{TiO}_{2}\right]-900$ composite showing no activity is not shown on the graph. (b) $\mathrm{CH}_{4}$ selectivity and production rates normalized by BET specific area for postcalcined samples, (c) $\mathrm{H}_{2}$ and $\mathrm{CH}_{4}$ production rates for pre-calcined $\mathrm{Au} / \mathrm{TiO} \mathrm{O}_{2}$ composites, and (d) $\mathrm{CH}_{4}$ selectivity and production rates normalized by BET specific area for precalcined samples.

Only $43 \%, 6 \%$ and $1.3 \%$ of the initial surface area of the $\mathrm{Au}_{3 \mathrm{~nm}} / \mathrm{TiO}_{2}$ composite $\left(315 \mathrm{~m}^{2} \mathrm{~g}^{-1}\right)$ is indeed retained a er calcination at $450{ }^{\circ} \mathrm{C}, 700{ }^{\circ} \mathrm{C}$ and $900{ }^{\circ} \mathrm{C}$, respectively. Hence, by normalizing the photocatalytic productions with the speciftc surface area of the photocatalyst, average methane production rates are found to actually increase with increasing calcination temperature, from 23 to 43 and $85 \mathrm{nmolh}^{-1} \mathrm{~m}^{-2}$, when calcining at $450^{\circ} \mathrm{C}$ and $700^{\circ} \mathrm{C}$, respectively (Fig. $2 \mathrm{~b}$ ). This is attributed to the increasing degree of crystallinity of the semi-conductor particles, as evidenced by the narrowing of e.g. the (004) anatase re $\square$ ection at $2 q^{1 / 4} 38^{\circ}$ in the powder X-ray diffractograms of the composites (Fig. 4).

The $\mathrm{Au}-\mathrm{TiO}_{2}$ interface may also contribute to the increase in surface speciftc methane production rates, as shown by the change in the optical response of the composites upon calcination. The UV-vis spectra (Fig. 5a) indeed exhibit a major absorbance over the UV range, which is attributed to electronic transitions within the titania SC, as well as a smaller absorption in the visible range, typical of the localized surface plasmon resonance (LSPR) of gold nanoparticles. While the absorption related to bare titania ends at $400 \mathrm{~nm}$, the remaining absorbance of the $\mathrm{Au}-\mathrm{TiO}_{2}$ composites in the $400-500 \mathrm{~nm}$ range is attributed to $\mathrm{d}-\mathrm{d}$ interband transitions from the Au NPs. The most signiftcant effect of calcination temperature on the optical response of the composites is the increase in the relative intensity of the SPR and the major red-shi of the SPR position. Its maximum is indeed shi ed from $520 \mathrm{~nm}$ in $\mathrm{Au}_{3 \mathrm{~nm}} / \mathrm{TiO}_{2}$, which is typical of free Au NPs, i.e. Au NPsin weakinteraction with titania, to 545,575 and up to $605 \mathrm{~nm}$, when the compositeis calcined at $450^{\circ} \mathrm{C}$, $700{ }^{\circ} \mathrm{C}$ and $900{ }^{\circ} \mathrm{C}$, respectively. Although the increase in intensity is consistent with 

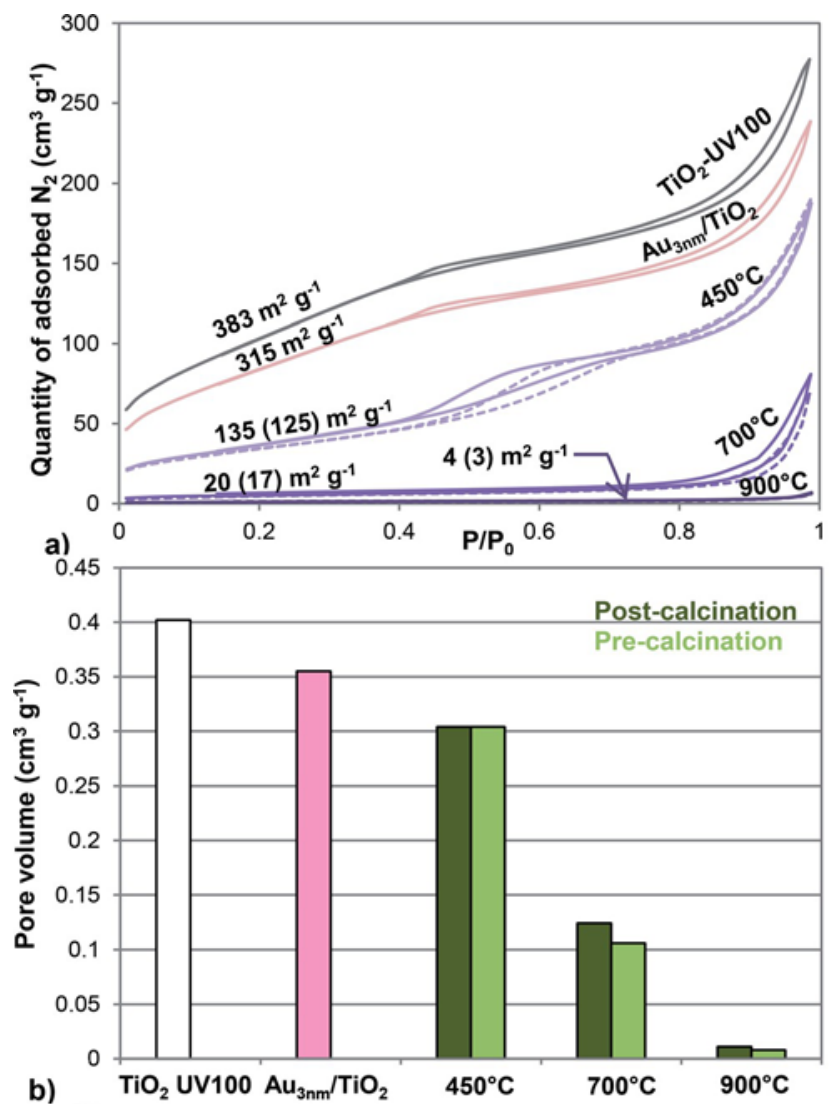

b)

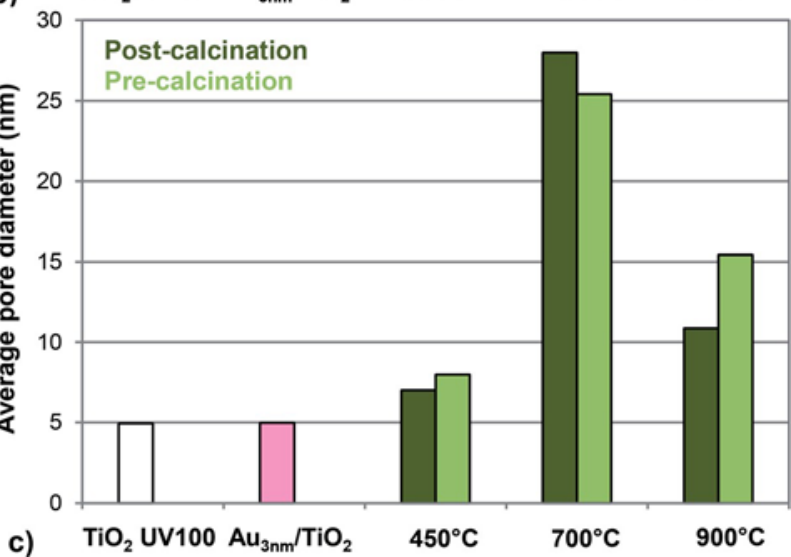

Fig. 3 (a) $\mathrm{N}_{2}$ physisorption isotherms of $\mathrm{TiO}_{2}, \mathrm{Au}_{3 \mathrm{~nm}} / \mathrm{TiO}_{2}$ and post-calcined samples with corresponding BET surface area values (BET surface area values for pre-calcined composites are in brackets). (b) Pore volume and (c) average pore diameters for $\mathrm{TiO}_{2}$, $\mathrm{Au}_{3 \mathrm{~nm}} / \mathrm{TiO}_{2}$, and pre- and post-calcined composites.

the increase in Au NP size from $3 \mathrm{~nm}$ to $43 \mathrm{~nm}$ as shown by TEM studies (Fig. 6 and Table 1), the extent of the red-shi cannot be accounted for solely by a size effect.

Such a shi implies a strengthening of the metal-support interaction, which was conftrmed by HRTEM studies (Fig. 7). Thermal treatment of the composite in 


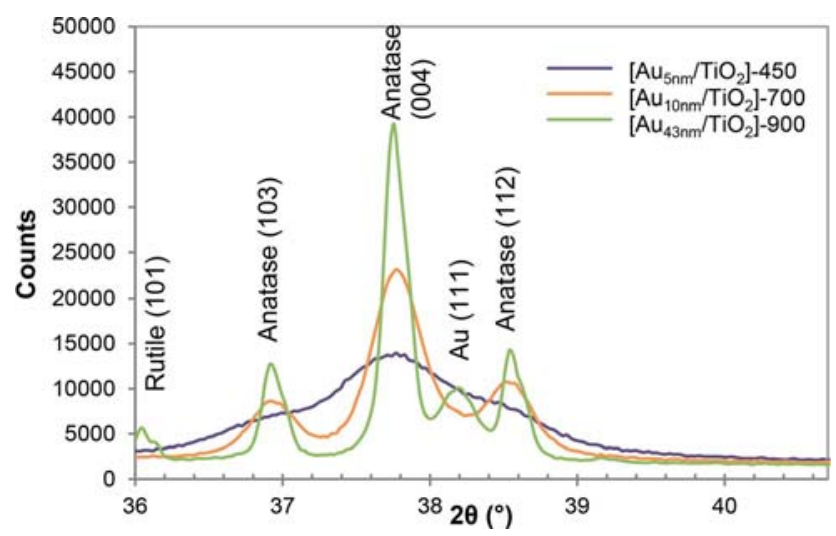

Fig. 4 Diffractograms of post-calcined samples $\left(450^{\circ} \mathrm{C}\right.$ is purple, $700{ }^{\circ} \mathrm{C}$ orange and $900{ }^{\circ} \mathrm{C}$ green).
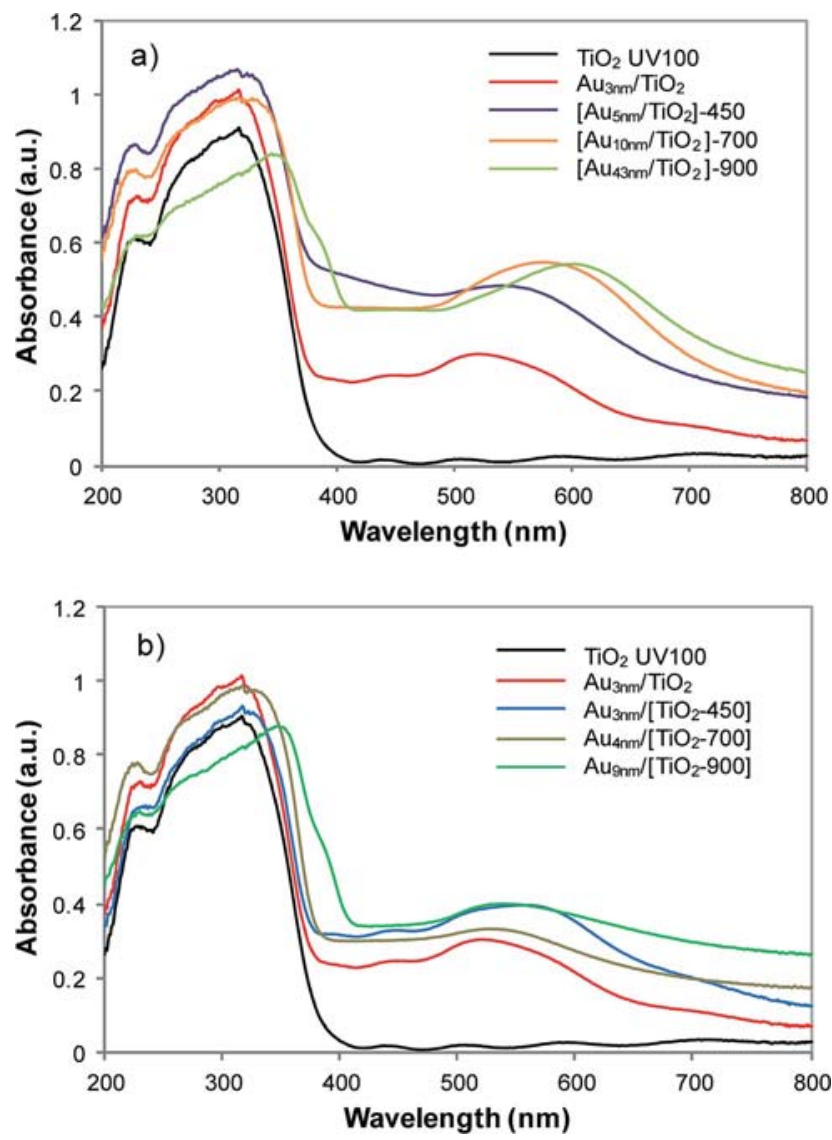

Fig. 5 UV-visible spectra of (a) $\mathrm{TiO}_{2}, \mathrm{Au}_{3 n \mathrm{~m}} / \mathrm{TiO}_{2}$ and post-calcined samples and (b) $\mathrm{TiO}_{2}$, $\mathrm{Au}_{3 \mathrm{~nm}} / \mathrm{TiO}_{2}$ and pre-calcined samples. 

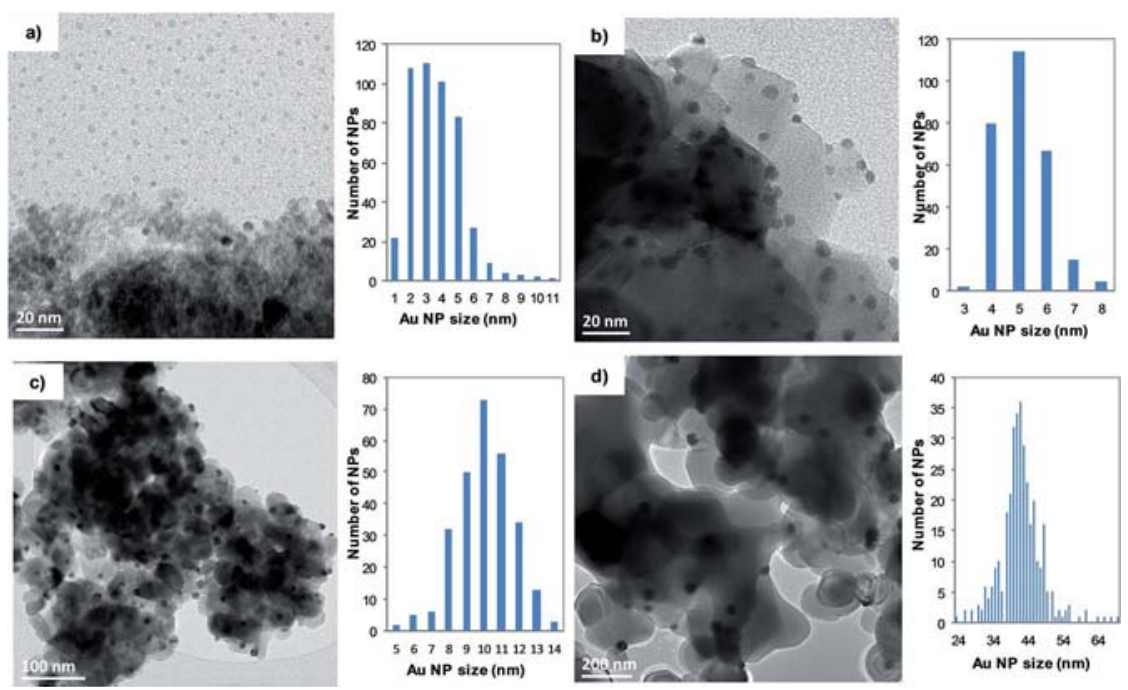

Fig. 6 Representative TEM images and Au NP size distributions of (a) $\mathrm{Au}_{3 n m} / \mathrm{TiO}_{2}$, (b) $\left[\mathrm{Au}_{5 \mathrm{~nm}} / \mathrm{TiO}_{2}\right]-450$, (c) $\left[\mathrm{Au}_{10 \mathrm{~nm}} / \mathrm{TiO}_{2}\right]-700$, and (d) $\left[\mathrm{Au}_{43 \mathrm{~nm}} / \mathrm{TiO}_{2}\right]-900$.

air indeed induces, from $700^{\circ} \mathrm{C}$, an interaction between gold and titania akin to the so-called strong metal-support interaction (SMSI), except it is here occurring upon oxidizing, and not reducing, heating. Inclusion of gold in the titania lattice is clearly observed in the composite treated at $700{ }^{\circ} \mathrm{C}$, while some particles become fully encapsulated within a layer of titanium oxide upon further air treatment at $900^{\circ} \mathrm{C}$ (Fig. 7). The former phenomenon has been described before for $\mathrm{Pt} / \mathrm{TiO}_{2}$ (ref. 29) and $\mathrm{Au} / \mathrm{TiO}_{2}$ (ref. 30) materials, while the latter (Au NP encapsulation) most likely contributes to the inactivity of $\left[\mathrm{Au}_{43 \mathrm{~nm}} / \mathrm{TiO}_{2}\right]-900$, by lowering the metallic surface beyond the loss coming from the drastic growth of $\mathrm{Au}$ NPs $(43 \mathrm{~nm})$. It suggests that the metallic surface and the $\mathrm{Au}-\mathrm{TiO}_{2}$ perimeter interface sites play key roles in the photoreduction process, not from their interaction with light, but rather as direct adsorption sites for reactants or intermediates. We speculate that accessible $\mathrm{Au}-\mathrm{TiO}_{2}$ perimeter sites, by enhancing the number of oxygen vacancies and defects, increase the rate of $\mathrm{CO}_{2}$ activation and that accessibility to the gold surface increases the rate of in situ formation of the reducing agent $\left(\mathrm{H}^{\circ}\right)$.

$\mathrm{TiO}_{2}$ pre-calcination effect

In order to evaluate theimpact of the crystallinity of the $\mathrm{SC}$ (quasi-)independently from the metallic surface, titania was calcined at $450^{\circ} \mathrm{C}, 700^{\circ} \mathrm{C}$ and $900^{\circ} \mathrm{C}$ before gold deposition. The $\mathrm{NaBH}_{4}$-protected $3 \mathrm{~nm}$ gold sol was subsequently immobilized on pre-calcined SCs. Hence, variations in Au NP size with calcination temperature, as well as variations in $\mathrm{Au}-\mathrm{TiO}_{2}$ interactions, are minimized, as shown by the modest red shi in the LSPR position (530-560 nm, Fig. 5b). Average $\mathrm{Au}$ NP sizes are found to be $3.6 \mathrm{~nm}, 3.9 \mathrm{~nm}$ and $9.0 \mathrm{~nm}$ in Au3nm/[ $\left.\mathrm{TiO}_{2}-450\right]$, $\mathrm{Au}_{4 \mathrm{~nm}} /\left[\mathrm{TiO}_{2}-700\right]$ and $\mathrm{Au}_{9 \mathrm{~nm}} /\left[\mathrm{TiO}_{2}-900\right]$, respectively (Experimental section, Table 1). Accordingly, the metallic dispersion, estimated on the basis of geometrical 


\begin{tabular}{llllll}
\hline Sample name & Metal & $\begin{array}{l}\mathrm{TiO}_{2} \text { pre- } \\
\text { calcination }\end{array}$ & $\begin{array}{l}\text { Post- } \\
\text { calcination }\end{array}$ & $\begin{array}{l}\text { Metal } \\
\text { loading }{ }^{a}(\mathrm{wt} \%)\end{array}$ & $\begin{array}{l}\text { M NPaverage } \\
\text { size }\end{array}$ (nm) \\
\hline $\mathrm{Au}_{3 \mathrm{~nm}} / \mathrm{TiO}_{2}$ & $\mathrm{Au}$ & $\mathrm{X}$ & $\mathrm{X}$ & $1.2 \mathrm{~T} 0.03$ & $3.6 \mathrm{~T} 1.5$ \\
{$\left[\mathrm{Au}_{5 \mathrm{~nm}} / \mathrm{TiO}_{2}\right]-450$} & $\mathrm{Au}$ & $\mathrm{X}$ & $450{ }^{\circ} \mathrm{C}$ & $1.3 \mathrm{~T} 0.03$ & $5.1 \mathrm{~T} 0.9$ \\
{$\left[\mathrm{Au}_{10 \mathrm{~nm}} / \mathrm{TiO}_{2}\right]-700$} & $\mathrm{Au}$ & $\mathrm{X}$ & $700^{\circ} \mathrm{C}$ & $1.3 \mathrm{~T} 0.03$ & $10.0 \mathrm{~T} 1.6$ \\
{$\left[\mathrm{Au}_{43 \mathrm{~nm}} / \mathrm{TiO}_{2}\right]-900$} & $\mathrm{Au}$ & $\mathrm{X}$ & $900^{\circ} \mathrm{C}$ & $1.3 \mathrm{~T} 0.03$ & $42.3 \mathrm{~T} 6.0$ \\
$\mathrm{Au}_{3 \mathrm{~nm}} /\left[\mathrm{TiO}_{2}-450\right]$ & $\mathrm{Au}$ & $450{ }^{\circ} \mathrm{C}$ & $\mathrm{X}$ & $1.05 \mathrm{~T} 0.03$ & $3.6 \mathrm{~T} 1.3$ \\
$\mathrm{Au}_{4 \mathrm{~nm}} /\left[\mathrm{TiO}_{2}-700\right]$ & $\mathrm{Au}$ & $700{ }^{\circ} \mathrm{C}$ & $\mathrm{X}$ & $0.49 \mathrm{~T} 0.01$ & $3.9 \mathrm{~T} 1.0$ \\
$\mathrm{Au}_{5 \mathrm{~nm}} /\left[\mathrm{TiO}_{2}-700\right]-2$ & $\mathrm{Au}$ & $700{ }^{\circ} \mathrm{C}$ & $\mathrm{X}$ & $0.74 \mathrm{~T} 0.01$ & $4.7 \mathrm{~T} 1.7$ \\
$\mathrm{Au}_{9 \mathrm{~nm}} /\left[\mathrm{TiO}_{2}-900\right]$ & $\mathrm{Au}$ & $900{ }^{\circ} \mathrm{C}$ & $\mathrm{X}$ & $0.91 \mathrm{~T} 0.02$ & $9.0 \mathrm{~T} 4.2$ \\
$\mathrm{Au}_{15 \mathrm{~nm}} / \mathrm{TiO}_{2}$ & $\mathrm{Au}$ & $\mathrm{X}$ & $\mathrm{X}$ & $1.09 \mathrm{~T} 0.03$ & n.d. \\
$\mathrm{Au}_{50 \mathrm{~nm}} / \mathrm{TiO}_{2}$ & $\mathrm{Au}$ & $\mathrm{X}$ & $\mathrm{X}$ & $1.30 \mathrm{~T} 0.03$ & n.d. \\
$\mathrm{Pt}_{3 \mathrm{~nm}} / \mathrm{TiO}_{2}$ & $\mathrm{Pt}$ & $\mathrm{X}$ & $\mathrm{X}$ & $0.77 \mathrm{~T} 0.06$ & $3.0 \mathrm{~T} 0.8$ \\
{$\left[\mathrm{Pt}_{3 \mathrm{~nm}} / \mathrm{TiO}_{2}\right]-700$} & $\mathrm{Pt}$ & $\mathrm{X}$ & $700{ }^{\circ} \mathrm{C}$ & $0.86 \mathrm{~T} 0.06$ & n.d.
\end{tabular}

${ }^{a}$ Determined by ICP-AES. ${ }^{b}$ Determined by TEM.

calculations ${ }^{31}$ at $43 \%$ in the original sol and at $37 \%$ in the uncalcined $\mathrm{Au} 3 \mathrm{~m} / \mathrm{TiO}_{2}$ composite, remains similar when the support is pre-calcined at $450{ }^{\circ} \mathrm{C}$ and $700{ }^{\circ} \mathrm{C}$ ( $37 \%$ and $35 \%$, respectively). The $\mathrm{Au}-\mathrm{TiO}_{2}$ perimeter interface is thus expected to be unchanged in those samples. Pre-calcining $\mathrm{TiO}_{2}$ at $900{ }^{\circ} \mathrm{C}$, however, induces a huge drop in surface area. Longer reaction times are thus needed to load the support with a similar amount of gold (see Experimental section), which favours aggregation and sintering of the deposited NPs (TEM, not shown). In this case, the metallic dispersion decreases to $16 \%$, but remains much higher than in the postcalcined counterpart (ca. 4\%) and the NPs are much more accessible. Structural characterization (XRD, not shown) shows that anatase crystallites grow with increasing temperature in the same manner as in the post-calcined $\mathrm{Au} / \mathrm{TiO}_{2}$ composites. The speciftc surface area decreases accordingly: only $40 \%, 5.4 \%$ and $0.95 \%$ of the initial surface area of the $\mathrm{Au} 3 \mathrm{~nm} / \mathrm{TiO}_{2}$ composite $\left(315 \mathrm{~m}^{2} \mathrm{~g}^{-1}\right)$ is retained when $\mathrm{TiO}_{2}$ is pre-calcined at $450{ }^{\circ} \mathrm{C}, 700{ }^{\circ} \mathrm{C}$ and $900{ }^{\circ} \mathrm{C}$, respectively. Nevertheless, Au3nm/[ $\left.\mathrm{TiO}_{2}-450\right]$ produces signiftcantly more methane (and hydrogen) than the uncalcined, poorly crystallized $\mathrm{Au}_{3 \mathrm{~nm}} / \mathrm{TiO}_{2}$ composite, setting a new standard in solar $\mathrm{CH}_{4}$ production of $13 \mathrm{mmolh}^{-1} \mathrm{~g}^{-1}$, i.e. $291 \mathrm{~mL} \mathrm{~h}^{-1} \mathrm{~g}^{-}$ 1

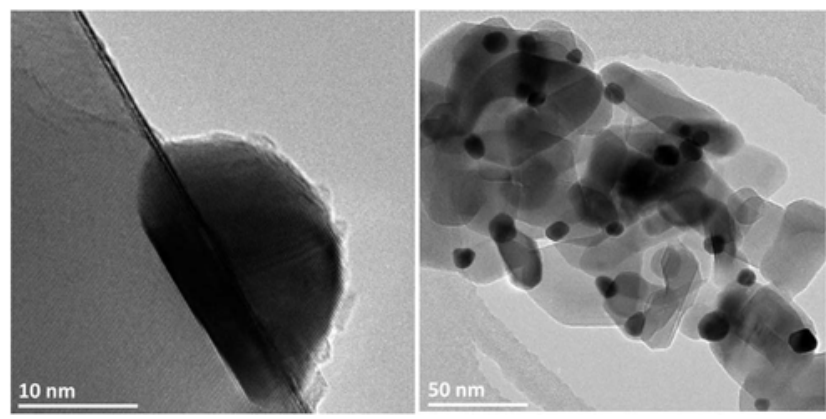

Fig. 7 HRTEM images of (left) $\left[\mathrm{Au}_{43 \mathrm{~nm}} / \mathrm{TiO}_{2}\right]-900$ and (right) $\left[\mathrm{Au}_{10 \mathrm{~nm}} / \mathrm{TiO}_{2}\right]-700$. 
(Fig. 2c). Crystallization of the $\mathrm{SC}$ is thus beneftcial to the photoreduction of $\mathrm{CO}_{2}$. In fact, surface speciftc (i.e. speciftc surface area-normalized) $\mathrm{CH}_{4}$ production rates increase with increasing pre-calcination temperature, i.e. crystallinity, of the titania support from $23 \mathrm{nmol} \mathrm{h}^{-1} \mathrm{~m}^{-2}$ in the uncalcined, poorly crystallized $\mathrm{Au}_{3 \mathrm{~nm}} / \mathrm{TiO}_{2}$ composite to 104 and $130 \mathrm{nmol} \mathrm{h}^{-1} \mathrm{~m}^{-2}$, when pre-calcining $\mathrm{TiO}_{2}$ at $450{ }^{\circ} \mathrm{C}$ and $700{ }^{\circ} \mathrm{C}$, respectively (Fig. 2d). Additionally, the surface-normalized $\mathrm{CH}_{4}$ production of Au9nm/[ $\left.\mathrm{TiO}_{2}-900\right]\left(33 \mathrm{nmolcH}_{4} \mathrm{~h}^{-1} \mathrm{~m}^{-2}\right)$ remains higher than that of the uncalcined composite. Crystallization of the titania SC is thus clearly favourable to the solar photocatalytic process. An increasing degree of crystallinity may indeed increase the lifetime of the charge carriers (Time Resolved Microwave Conductivity (TRMC) measurements) by avoiding defect-induced recombination..$^{32}$ Yet, the surface-speciftc methane production rate observed over the most crystallized sample, $\mathrm{Au}_{9 \mathrm{~nm}} /\left[\mathrm{TiO}_{2}-900\right]$, is lower than those of the composites calcined at lower temperatures. It is attributed to the signiftcantly decreased density of defects and oxygen vacancies in the highly crystallized structure (presence of the rutile phase, Fig. 4), which may induce less efficient adsorption of the carbon dioxide reactant per surface unit. In addition, the lower gold dispersion of Au9nm/[ $\left.\mathrm{TiO}_{2}-900\right]$, as compared with $\mathrm{Au}_{3 \mathrm{~nm}} /\left[\mathrm{TiO}_{2}-450\right]$ and $\mathrm{Au}_{4 \mathrm{~nm}} /\left[\mathrm{TiO}_{2}-700\right]$, may also contribute to its lower BET-normalized activity.

Information about the impact of the actually accessible gold surface may be derived from comparison of the photocatalytic performances of the post-calcined and pre-calcined series. Indeed, the physico-chemical properties of the SCs are similar in both series (similar anatase crystallite size, nitrogen physisorption isotherms, surface areas, pore volumes and pore size distributions (Fig. 3)), while the accessible metallic surface is generally greater in the pre-calcined series. Clearly, the pre-calcined series is more active than the post-calcined composites under solar conditions, at each calcination temperature (Fig. 2). In particular, $\mathrm{Au}_{3 \mathrm{~nm}} /\left[\mathrm{TiO}_{2}-450\right]$ exhibits more than twice the methane production rate of $\left[\mathrm{Au}_{5 \mathrm{~nm}} / \mathrm{TiO}_{2}\right]-450$, despite a moderate gain in accessible gold surface $(0.39 \mathrm{vs}$. $0.35 \mathrm{wt} \%$ ). Au9nm/[ $\left.\mathrm{TiO}_{2}-900\right]$, despite its the low surface area and unlike its postcalcined counterpart, exhibits measurable photocatalytic activity $\left(0.1 \mathrm{mmol}_{\mathrm{CH}_{4}} \mathrm{~h}^{-1}\right.$ $\left.\mathrm{g}^{-1}\right)$ which likely beneftts from the much higher (0.15 vs. $\left.0.05 \mathrm{wt} \%\right)$ and much more accessible $\mathrm{Au}$ surface content (no encapsulation). Finally, $\mathrm{Au}_{4 \mathrm{~nm}} /\left[\mathrm{TiO}_{2}-700\right]$ exhibits a slightly lower Au surface content $(0.17 \mathrm{wt} \%)$ than its post-calcined counter-part (0.20 wt\%), due to its peculiarly low Au loading $(0.49 \mathrm{wt} \%$ instead of $1.1 \mathrm{~T} 0.2 \mathrm{wt} \%$ in all other $\mathrm{Au} / \mathrm{TiO}_{2}$ composites). It nevertheless exhibits an activity gain of about $30 \%\left(2.2 \mathrm{mmolh}^{-1} \mathrm{~g}^{-1} \mathrm{vs.} 1.7 \mathrm{mmolh}^{-1} \mathrm{~g}^{-1}\right)$, likely due to the higher accessibility of gold (no inclusion in the $\mathrm{TiO}_{2}$ lattice). The accessible $\mathrm{Au}$ surface content could be marginally increased to $0.21 \mathrm{wt} \%$ by increasing adsorption time between the gold sol and $\mathrm{TiO}_{2}-700{ }^{\circ} \mathrm{C}$ (resulting in a moreloaded Ausnm/[TiO2-700]-2 composite (0.74 wt\%) with slightly increased NP size $(4.7 \mathrm{~nm})$ ), with no improvement however in $\mathrm{CH}_{4}$ production rate $\left(1.8 \mathrm{mmol} \mathrm{g}^{-1} \mathrm{~h}^{-1}\right)$. Fig. 8 shows that both pre-calcined materials exhibit signiftcantly higher Au NP densities $\left(>400 \mathrm{NPs}\right.$ permm $\left.{ }^{2}\right)$ than $\left[\mathrm{Au}_{10 \mathrm{~nm}} / \mathrm{TiO}_{2}\right]-700$. This suggests that gold may play a dual role in the photocatalytic process and that the catalytic role of its available surface may be partially counterbalanced by its role as a recombination center when the density of M NPs on the titania surface is high. ${ }^{33}$

Concerning selectivity to methane $v s . \mathrm{H}_{2}$, the initial selectivity of the uncalcined $\mathrm{Au}_{3 \mathrm{~nm}} / \mathrm{TiO}_{2}$ composite (60\%) increases when applying calcination at $450{ }^{\circ} \mathrm{C}$ 


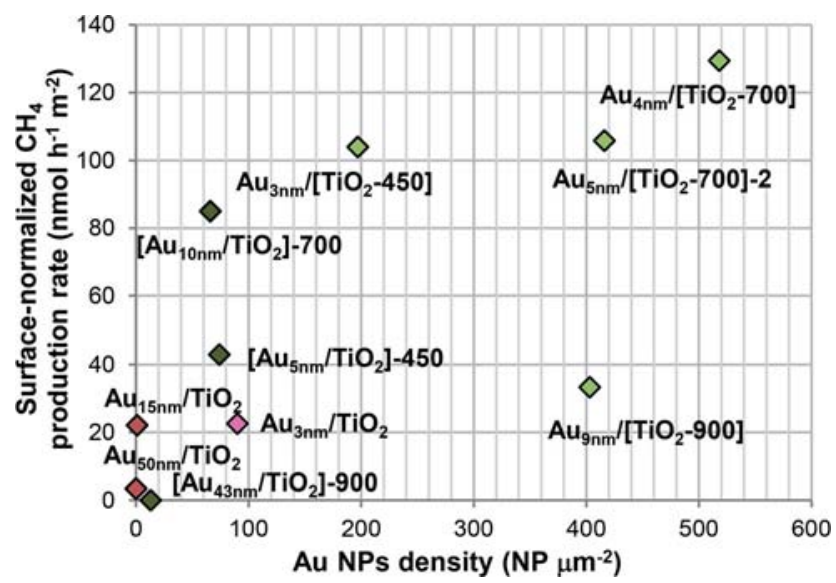

Fig. 8 BET surface normalized $\mathrm{CH}_{4}$ production rates for uncalcined $(; 4$, pre-calcined () and post-calcined ( ) samples.

to $63 \%$ for post-calcination and to $78 \%$ for pre-calcination. It may be attributed to the loss of terminating hydroxyl functional groups of the SC surface (dehydroxylation, TGA, not shown), which contribute preferentially to $\mathrm{H}_{2}$ production. ${ }^{34}$ The even higher selectivity of the pre-calcined composite is attributed to the more numerous population of $\mathrm{Au}-\mathrm{TiO}_{2}$ interface perimeter sites due to the presence of a higher density of Au NPs (197 vs. 74 NP per mm², Fig. 8), which results from the smaller Au NP size (3.6 nm), similar loading and slightly lower surface area (125 vs. $135 \mathrm{~m}^{2} \mathrm{~g}^{-1}$ ). The decrease in $\mathrm{CH}_{4}$ selectivity upon further increasing the calcination temperature, i.e. the crystallization degree of titania, is correlated to the loss of surface defects, i.e. the sites that favour $\mathrm{CO}_{2}$ over water adsorption. ${ }^{24}$

\section{Au NP size effect}

In order to probe the Au NP size effect, i.e. the effect of metallic dispersion, two commercially available PVP-protected gold colloids of $15 \mathrm{~nm}$ and $50 \mathrm{~nm}$ were loaded on the uncalcined $\mathrm{TiO}_{2}$ UV100 support (see Experimental section) in the same amount (1.1 T $0.2 \mathrm{wt} \%)$. In turn, the density of the Au NPs is also modifted: it decreases signiftcantly with increasing $\mathrm{Au} N \mathrm{NP}$ size. $\mathrm{Au}_{3 \mathrm{~nm}} / \mathrm{TiO}_{2}$ and $\mathrm{Au}_{15 \mathrm{~nm}} / \mathrm{TiO}_{2}$ lead to the same methane production rate $\left(7.1 \mathrm{mmol} \mathrm{h}^{-1} \mathrm{~g}^{-1}\right.$, Fig. 9a), despite the much lower gold dispersion in $\mathrm{Au}_{15 \mathrm{~nm}} / \mathrm{TiO}_{2}$ (10\% instead of $37 \%$ ). This suggests that methane production is not directly related to metal dispersion, which also implies that catalytic effects are not limiting. Such low impact of Au NP size (in the 3-12 $\mathrm{nm}$ range) on the photocatalytic efficiency has previously been observed in titania-based hydrogen production from water/ethanol mixtures. ${ }^{35} \mathrm{Au}_{15 \mathrm{~nm}} / \mathrm{TiO}_{2}$ leads to the optimum internal quantum yield of this study, i.e. $0.012 \%$ with only $1 \%$ of UV photons emitted. Further increasing the Au NP diameter to $50 \mathrm{~nm}$, i.e. lowering the metal dispersion to about $1 \%$, causes a drop in the methane production rate to $1.3 \mathrm{mmol} \mathrm{h}^{-1} \mathrm{~g}^{-1}$. It is interesting that the activity of Ausonm/ $\mathrm{TiO}_{2}$ is close to that of the bare titania support. This is consistent with the fact that the density of Au NPs is particularly low in this composite ( $0.1 \mathrm{NP}$ per $\mathrm{mm}^{2}$ ). By increasing the Au NP size on the same support (identical surface area), the 


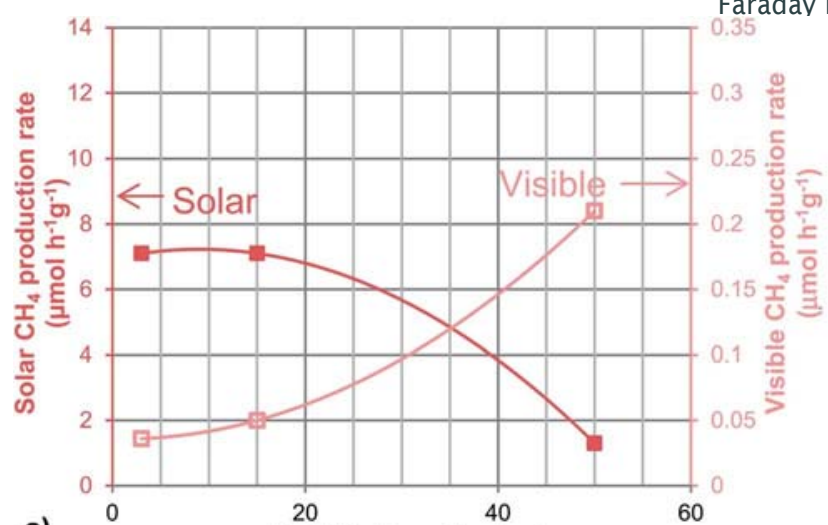

a)

Au NPs diameter $(\mathrm{nm})$

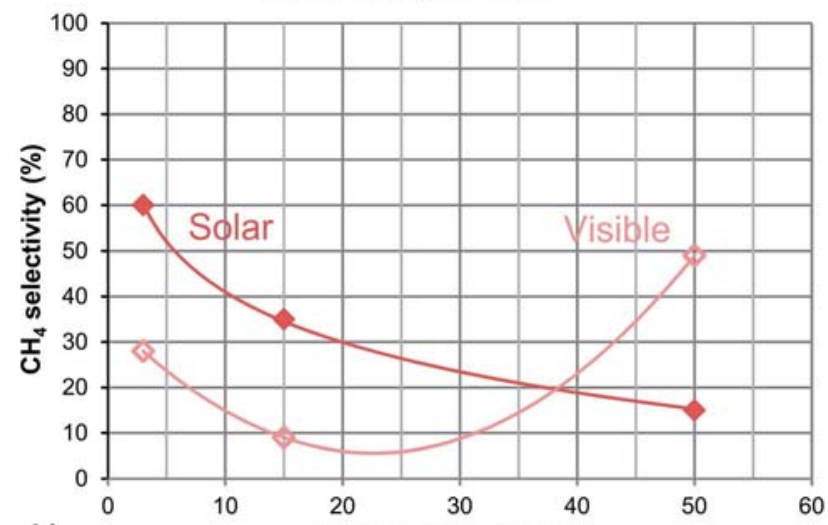

b)

Au NPs diameter $(\mathrm{nm})$

Fig. 9 (a) Comparison of visible ( $)$ and solar $(\square) \mathrm{CH}_{4}$ production rates as a function of $\mathrm{Au}$ NP size. (b) Comparison of $\mathrm{CH}_{4}$ selectivity under visible $\left.(>420 \mathrm{~nm}\rangle,\right)$ and solar light $(\diamond)$ as a function of Au NP size.

decrease in Au dispersion is indeed accompanied by an even more signiftcant decrease in Au NPdensity, from 90 NPs per mm ${ }^{2}$ in $\mathrm{Au}_{3} \mathrm{~nm} / \mathrm{TiO}_{2}$ to $1 \mathrm{NP}^{\mathrm{N}}$ er mm${ }^{2}$ and $0.1 \mathrm{NP}$ per $\mathrm{mm}^{2}$ in $\mathrm{Au}_{15 \mathrm{~nm}} / \mathrm{TiO}_{2}$ and $\mathrm{Au}_{50 \mathrm{~nm}} / \mathrm{TiO}_{2}$, respectively. At such a low $\mathrm{Au}$ NP density, the positive impact of gold on the titania-based photocatalytic activity is modest. Nevertheless, the selectivity to methane continuously decreases with increasing Au NP size, from 60\% in $\mathrm{Au}_{3 \mathrm{~nm}} / \mathrm{TiO}_{2}$ to $15 \%$ in $\mathrm{Au}_{50 \mathrm{~nm}} / \mathrm{TiO}_{2}$, suggesting that larger particles favour the reaction of $\mathrm{H}^{\circ}$ with $\mathrm{H}^{\circ}$ rather than with carbonaceous species. Larger Au NPs have previously been found active for hydrogen production from water, suggesting that $\mathrm{H}^{\circ}+\mathrm{H}^{\circ}$ recombination may indeed occur on the surface of large Au NPs. ${ }^{36,37}$ More generally, larger Au NPs are reported active for radical recombination. ${ }^{38,39}$ On the other hand, the decreasing $\mathrm{Au}$ NP density decreases the number of $\mathrm{Au}-\mathrm{TiO}_{2}$ perimeter interface sites, i.e. the number of $\mathrm{CO}_{2}$ adsorption sites, which would decrease the probability for $\mathrm{CO}_{2}$ activation and subsequent reduction to $\mathrm{CH}_{4}$. Such a decrease in $\mathrm{CH}_{4}$ vs. $\mathrm{H}_{2}$ selectivity with increasing Au NP size is thus consistent with a reaction pathway involving $\mathrm{H}^{\circ}$ recombination over the gold surface and $\mathrm{H}^{\circ}+\mathrm{CO}_{2} *$ reaction at the $\mathrm{Au}-\mathrm{TiO}_{2}$ perimeter interface. 
Activity in the visible range

In order to probe the activity of the samples in the visible range, a solidftlter (GG420 Farbglass SCHOTT from ITOS) that cuts-off irradiation below $420 \mathrm{~nm}$ was applied. Under these conditions, the overall photon $\square \mathrm{ux}\left(0.028 \mathrm{~mol} \mathrm{~s}^{-1} \mathrm{~m}^{-2}\right)$ is decreased by about $15 \%$, to $0.024 \mathrm{~mol} \mathrm{~s}^{-1} \mathrm{~m}^{-2}$. Bare UV100 is no longer active for $\mathrm{CO}_{2}$ photoreduction and hydrocarbon or hydrogen production (if any) falls below the detection limit. The gold-containing composites, however, all exhibit measurable activity, with average methane production rates ranging from 0.02 to $0.31 \mathrm{mmol} \mathrm{h}^{-1}$ $\mathrm{g}^{-1}$, i.e. 0.11 to $7.06 \mathrm{nmol} \mathrm{h}^{-1} \mathrm{~m}^{-2}$ (Fig. 10). This occurs in the absence of measurable photon absorption from $\mathrm{TiO}_{2}$ anatase above $400 \mathrm{~nm}$, i.e. in the absence of direct light-mediated activation of the titania SC (Fig. 5). This suggests that the active charge carriers are not generated directly within the $\mathrm{SC}$, but rather via the gold nanoparticles. The optical properties of Au NPs and more speciftcally their LSPR in the visible range are known to induce the formation of hot electrons upon excitation at the corresponding wavelengths. ${ }^{8-13}$ Such plasmon-derived hot electrons are reported to induce a variety of phenomena, including direct chemical reaction with adsorbates at the $\mathrm{M}$ NP surface ${ }^{10,15,40,41}$ and enrichment of the conduction band of the SC by transfer of these hot carriers from the Au NP to the $\mathrm{SC},{ }^{9-14}$ in addition to enhanced charge separation. ${ }^{10,42}$ Their lifetime, which is increased by the interaction of the metal nanoparticle with the SC viaformation of a Schottky barrier, does indeed match the chemical reaction rates.

The plasmon-related activities observed here are typically one to two orders of magnitude lower than the direct, SC-based photocatalytic process, keeping in
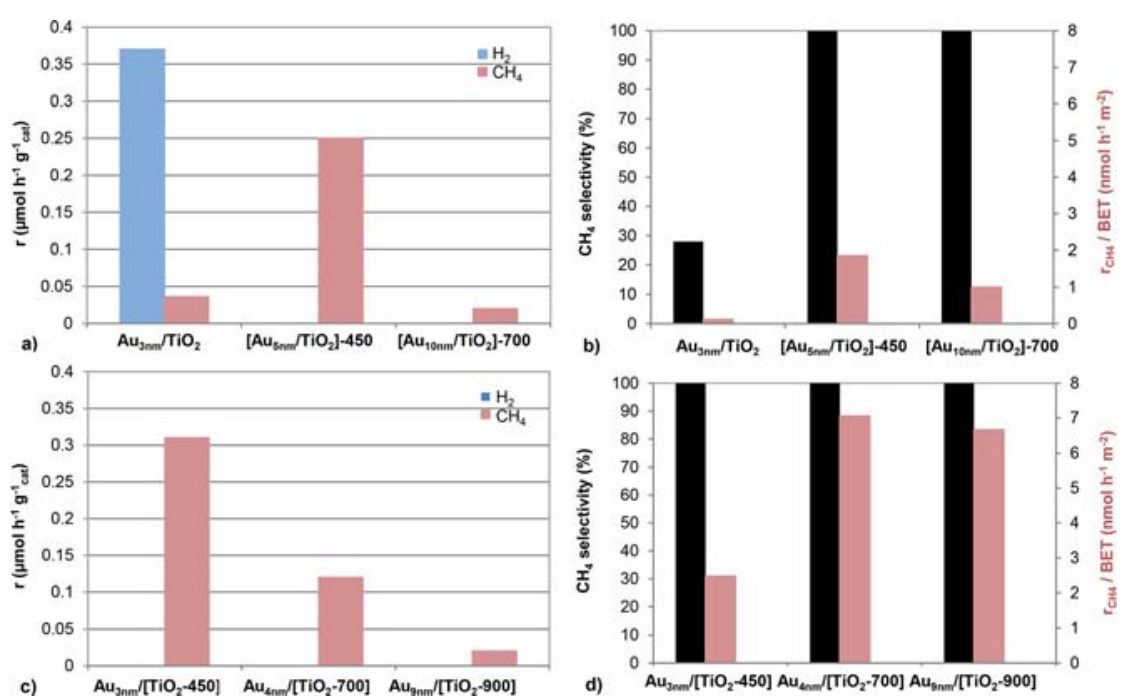

c)

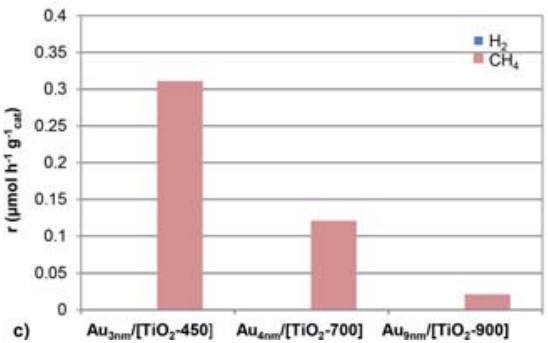

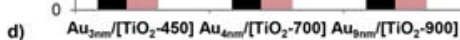

Fig. 10 (a) $\mathrm{H}_{2}$ and $\mathrm{CH}_{4}$ production rates for $\mathrm{Au}_{3 \mathrm{~nm}} / \mathrm{TiO}_{2}$ and post-calcined samples under visible light $(>420 \mathrm{~nm})$. The $\left[\mathrm{Au}_{43 \mathrm{~nm}} / \mathrm{TiO}_{2}\right]-900$ composite showing no activity is not shown on the graph. (b) $\mathrm{CH}_{4}$ selectivity and production rates normalized by BET specific surface area for post-calcined samples under visible light (>420 nm), (c) $\mathrm{H}_{2}$ and $\mathrm{CH}_{4}$ production rates for pre-calcined samples under visible light $(>420 \mathrm{~nm})$, and (d) $\mathrm{CH}_{4}$ selectivity and production rates normalized by BET specific area for pre-calcined samples under visible light (>420 nm). 
mind that visible light irradiance with the UV-cut-off ftlter was $4600 \mathrm{~W} \mathrm{~m}^{-2}$ compared to $5100 \mathrm{~W} \mathrm{~m}^{-2}$ without the ftlter. Comparing the performance of all

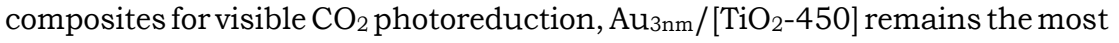
active of the series on a weight basis, producing $0.31 \mathrm{mmol}_{\mathrm{CH}_{4}} \mathrm{~h}^{-1} \mathrm{~g}^{-1}$ under visible light (Fig. 10c), which is about ten times more than on $\mathrm{Au}_{3 \mathrm{~nm}} / \mathrm{TiO}_{2}$ (Fig. 10a) followed by $\left[\mathrm{Au}_{5 \mathrm{~nm}} / \mathrm{TiO}_{2}\right]-450\left(0.25 \mathrm{mmol}_{\mathrm{CH}_{4}} \mathrm{~h}^{-1} \mathrm{~g}^{-1}\right)$ and $\mathrm{Au}_{50 \mathrm{~nm}} / \mathrm{TiO}_{2}$ (0.21 $\mathrm{mmolcH}_{4} \mathrm{~h}^{-1} \mathrm{~g}^{-1}$ ) (Fig. 9a). The surface area remains an important factor, as methane production rates steadily decrease with decreasing surface area/ increasing Au NP density in the pre-calcined series to 0.12 and $0.02 \mathrm{mmol} \mathrm{h}^{-1}$ $\mathrm{g}^{-1}$ for $\mathrm{Au}_{4 \mathrm{~nm}} /\left[\mathrm{TiO}_{2}-700\right]$ and $\mathrm{Au}_{9 \mathrm{~nm}} /\left[\mathrm{TiO}_{2}-900\right]$, respectively. However, the most crystallized samples exhibit the highest surface-normalized activities of 6.67 and $7.06 \mathrm{nmol} \mathrm{h}^{-1} \mathrm{~m}^{-2}$ for Augnm/[TiO $\left.2-900\right]$ and $\mathrm{Au}_{4 \mathrm{~nm}} /\left[\mathrm{TiO}_{2}-700\right]$, respectively (Fig. 10d), highlighting the even higher importance of the crystallization of the SC in the plasmon-based process, as compared with the solar-induced, direct, SCbased process. Further impact of the degree of crystallization of titania can be seen by comparing "residual" activities (i.e. visible $v$ s. solar activity ratios) in the pre-calcined series: residual activities indeed increase upon increasing calcination temperature (Fig. 11b), i.e. with increasing titania crystallinity (Fig. 4), with Augnm/[TiO $2-900]$ exhibiting the maximum residual methane production rate upon pure visible irradiation (20\% of the solar activity).

The plasmon-based process also exhibits one major speciftcity: all calcined composites are apparently $100 \%$ selective towards methane, the amount of produced hydrogen (if any) being below the detection limit. On the other hand, uncalcined composites, except for $\mathrm{Au}_{50 \mathrm{~nm}} / \mathrm{TiO}_{2}$, exhibit a much lower $\mathrm{CH}_{4}$ selectivity under visible light than under solar irradiation (Fig. 9b). The beneftcial effect of the $\mathrm{SC}$ crystallization on the $\mathrm{CH}_{4} v s . \mathrm{H}_{2}$ selectivity is thus exacerbated upon visible-only irradiation. In particular, the most crystallized composites (calcined at $700^{\circ} \mathrm{C}$ and $900^{\circ} \mathrm{C}$ ) exhibit the same complete methane selectivity as the composites calcined at $450^{\circ} \mathrm{C}$, despite the lower density of defects which is unfavourable for $\mathrm{CH}_{4}$ adsorption. Hence the absence of unselective surface hydroxyl groups is not sufficient to account for the total selectivity to methane. Another phenomenon might contribute to the absence of hydrogen product. Molecular hydrogen is indeed known to readily dissociate over plasmon-activated Au NPs. ${ }^{15,40,43}$ Hence, even if it was formed in the present water-mediated $\mathrm{CO}_{2}$ photoreduction process, it would not be stable. One may also speculate that it may simply not be formed as it is in the SC-based process and that $\mathrm{H}^{\circ}+\mathrm{H}^{\circ}$ recombination simply does not occur in the gold-driven, plasmon-based process. In addition to the instability of the hydrogen molecule under plasmonic conditions, the absence of UV irradiation, which is known to enhance formation of defects on titania, ${ }^{44,45}$ may alsolower the possibility of $\mathrm{CO}_{2}$ adsorbing on titania. Under visible-only irradiation, $\mathrm{CO}_{2}$ adsorption and activation would thus be restricted to the gold surface, where it would more efficiently compete with $\mathrm{H}^{\circ}$, especially on dehydroxylated titania surfaces which likely lower the reverse spillover rate of $\mathrm{H}^{\circ} .{ }^{46}$ Consumption of in situ formed hydrogen in the direct hydrogenation of $\mathrm{CO}_{2}$ is less likely since gold is active for the reverse water-gas shi reaction leading to $\mathrm{CO}\left(\mathrm{CO}_{2}+\mathrm{H}_{2} / \mathrm{CO}+\mathrm{H}_{2} \mathrm{O}\right)$ and not for $\mathrm{CO}_{2}$ methanation leading to methane $\left(\mathrm{CO}_{2}+4 \mathrm{H}_{2} / \mathrm{CH}_{4}+2 \mathrm{H}_{2} \mathrm{O}\right),{ }^{47}$ which could not account for the $\mathrm{CH}_{4}$ product formed here. 

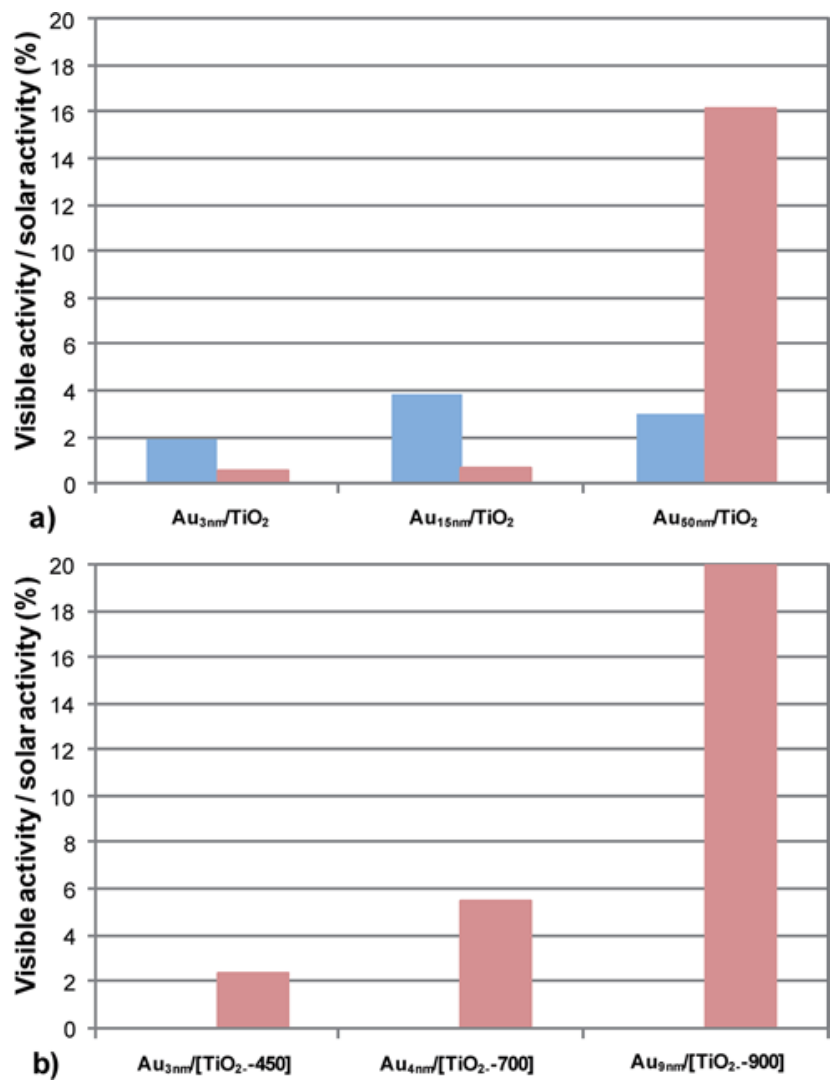

Fig. 11 Visible/solar activity ratio for uncalcined (a) and pre-calcined (b) samples.

Additionally, the pre-calcined materials (Fig. 10c and d) remain more active than their post-calcined counter-parts (Fig. 10a and b) under visible irradiation, showing that accessibility of the metal surface (and $\mathrm{Au}-\mathrm{TiO}_{2}$ interface) remains key in the plasmon-based process. However, the visible $\mathrm{CH}_{4}$ production rates (Fig. 9a), as well as the visible $v$ s. solar activity ratio (Fig. 11a), increase with increasing Au NP size (i.e. with decreasing metallic surface). Au $50 \mathrm{~nm} / \mathrm{TiO}_{2}$ retains $16 \%$ of activity upon pure visible irradiation, the second highest of the series, just a er the most crystallized composite and despite the poor crystallinity of the uncalcined titania support. Larger Au NPs are thus found to be more efficient for plasmon-derived $\mathrm{CO}_{2}$ photoreduction, in agreement with previous reports. ${ }^{15,48,49}$ This suggests that the optical properties of gold prevail over the use of the gold surface in the plasmon-induced process. The intensity of the SPR indeed increases with increasing Au NP size, enhancing hot electron generation. ${ }^{49,50}$ In our composites, the plasmon-driven process thus appears limited by the initial charge generation, which may be due to the low metal loading used, as compared with those used in plasmonicstudies. ${ }^{40,48,49}$

Platinum vs. gold

Further evidence of gold involvement in the plasmon-based process is obtained by comparison with two Pt-based photocatalysts prepared under similar 
conditions. Neither $\mathrm{Pt}_{3 \mathrm{~nm}} / \mathrm{TiO}_{2}$ nor $\left[\mathrm{Pt}_{3 \mathrm{~nm}} / \mathrm{TiO}_{2}\right]-700$ exhibit any detectable activity for $\mathrm{CO}_{2}$ photoreduction under visible light-only conditions. The position of the Pt NP LSPR in the UV range $(220 \mathrm{~nm})$ indeed prevents any Ptmediated $\mathrm{CO}_{2}$ photoreduction in the visible range. However, it may account for the much higher $\mathrm{CH}_{4}$ production rate observed over $\mathrm{Pt}_{3 \mathrm{~nm}} / \mathrm{TiO}_{2}$ under solar irradiation of $91 \mathrm{mmol}_{\mathrm{CH}_{4}} \mathrm{~h}^{-1} \mathrm{~g}^{-1}$. The one order of magnitudehigheractivity of Pt $v$ s. Au in the uncalcined composite may be explained by Plasmon Resonance Energy Transfer (PRET) i.e. the ability of the LSPR to enhance the electric fteld intensity in the SC, i.e. the ability of the LSPR to enhance light absorption by the $\mathrm{SC},{ }^{9}$ due to the overlap of the Pt LSPR and $\mathrm{TiO}_{2}$ absorption bands. The higher workfunction of platinum $v$ s. gold, which theoretically enhances charge separation, may also contribute to the higher solar activity of platinum. On the other hand, the activity of gold-based composites in the visible range is related to the inability of the SPR to transfer its energy to $\mathrm{TiO}_{2}$ and to the hot carriers generated within the gold nanoparticle as a result. It is interesting that the PRET phenomenon in the SC-based photoreduction of $\mathrm{CO}_{2}$ disappears with increasing crystallinity of titania and possible loss of accessible metallic surface via strong $\mathrm{Pt}-\mathrm{TiO}_{2}$ interactions. In the composites post-calcined at $700{ }^{\circ} \mathrm{C}$, surface-normalized $\mathrm{CH}_{4}$ production rates are indeed similar on $\mathrm{Pt}$ and $\mathrm{Au}\left(83 v \mathrm{~s} .85 \mathrm{nmol} \mathrm{h}^{-1} \mathrm{~m}^{-2}\right)$. The expected higher density of Pt $v s$. Au NPs in a low surface area $\left[\mathrm{Pt}_{3 \mathrm{~nm}} / \mathrm{TiO}_{2}\right]-700\left(29 \mathrm{~m}^{2} \mathrm{~g}^{-1}\right)$ may also inhibit the photocatalytic activity of this composite. Additionally, the initially higher selectivity of platinum towards $\mathrm{CH}_{4}$ vs. $\mathrm{H}_{2}$ formation of $88 \%$ decreases below that of gold in the calcined composite ( $31 \%$ vs. $46 \%)$.

\section{TRMC measurements and charge carrier dynamics}

The time resolved microwave conductivity method was previously used to determine the charge carrier lifetimes in $\mathrm{TiO}_{2}$-based composites ${ }^{21,33,51,52}$ The main data provided by TRMC are the maximum value of the signal $\left(I_{\max }\right)$, which indicates the number of excess charge carriers (mostly electrons) created by the pulse, includingdecay processes during the excitation by thelaser(10 ns), and the decay $(I(t))$ due to the decrease of mobile electrons, either by recombination or trapping processes. Concerning the decay, i.e. the lifetime of charge carriers, a short and long range are usually analyzed. The short-range decay, arbitrarily ftxed up to 40 ns a er the beginning of the pulse re $\square$ ects fast processes, recombination of charge carriers and/or trapping phenomena. ${ }^{51,52}$

At $360 \mathrm{~nm}$ excitation (Fig. 12), one can observe that the $\left[\mathrm{Au}_{5 \mathrm{~nm}} / \mathrm{TiO}_{2}\right]-450$ and $\mathrm{Au}_{3 \mathrm{~nm}} / \mathrm{TiO}_{2}$ samples lead to the most intense signal, followed by the $\mathrm{TiO}_{2} \mathrm{UV} 100$ support without Au NPs. However, the ftrst material exhibits slightly higher charge carrier generation accompanied with a lower signal decay, characteristic of either slower charge recombination dynamics or a more pronounced electron trapping effect. Comparing those samples with the $\mathrm{TiO}_{2} \mathrm{UV}_{100}$ support, it must be underlined that Au NP deposition does not lead to an important signal intensity decrease, as very o en observed a er metal nanoparticle deposition and resulting from the strong electron trapping effect attributed to Au NPs. Nevertheless, this trapping effect induced by Au NP deposition may be argued for the two photocatalysts presenting the largest $\mathrm{Au} \mathrm{NPs}$, i.e. Aus0nm $/ \mathrm{TiO}_{2}$ and mainly $\left[\mathrm{Au}_{10 \mathrm{~nm}} / \mathrm{TiO}_{2}\right]-700$. It is noted that absence of a signal does not mean that no 


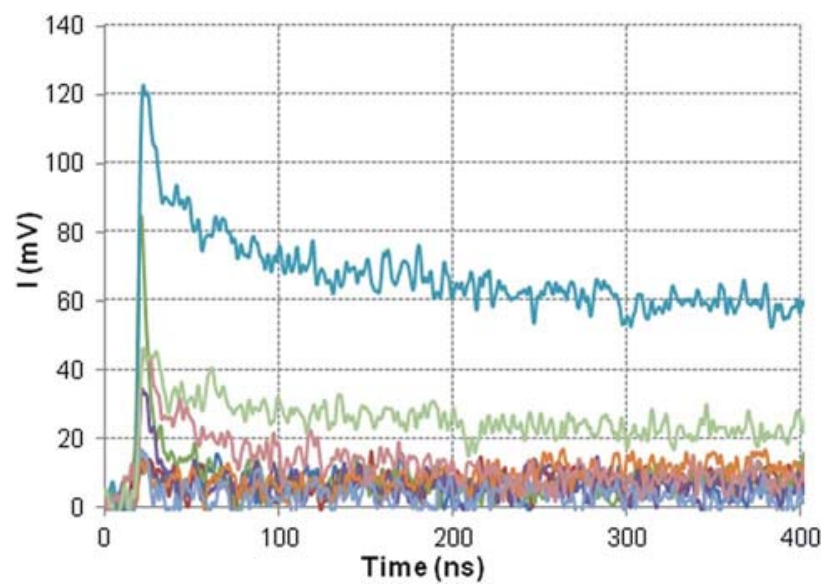

Fig. 12 TRMC signals at $360 \mathrm{~nm}$ on $\mathrm{TiO}_{2} \mathrm{UV} 100$ (pink), $\mathrm{TiO}_{2} \mathrm{P} 25$ (light green), $\mathrm{Au}_{3 \mathrm{~nm}} / \mathrm{TiO}_{2}$ (dark blue), $\left[\mathrm{Au}_{5 \mathrm{~nm}} / \mathrm{TiO}_{2}\right]-450$ (red), $\left[\mathrm{Au}_{10 \mathrm{~nm}} / \mathrm{TiO}_{2}\right]-700$ (dark green), $\mathrm{Au}_{3 \mathrm{~nm}} /\left[\mathrm{TiO}_{2}-450\right]$ (dark purple), $\mathrm{Au}_{4 \mathrm{~nm}} /\left[\mathrm{TiO}_{2}-700\right]$ (light blue), $\mathrm{Au}_{15 \mathrm{~nm}} / \mathrm{TiO}_{2}$ (orange) and $\mathrm{Au}_{50 \mathrm{~nm}} / \mathrm{TiO}_{2}$ (light purple).

charges were created but it could be correlated with very rapid charge recombination a er light excitation. It must also be noticed that $\mathrm{Au}_{4 \mathrm{~nm}} /\left[\mathrm{TiO}_{2}-700\right]$ presents speciftc features, with the lowest signal decay amongst all the samples. This can be correlated either with low charge carrier recombination kinetics or with higher electron trapping effects. It might be supposed that the presence of the rutile phase due to the prior thermal treatment of $\mathrm{TiO}_{2} \mathrm{UV} 100$ at $700{ }^{\circ} \mathrm{C}$, in intimate contact with the anatase phase, and the resulting formation of a nanoheterojunction between both phases lead to spatial charge separation, thus limiting their recombination.

At $450 \mathrm{~nm}$ excitation (in the blue region of visible light, Fig. 13), $\mathrm{Au}_{4 \mathrm{~nm}} /\left[\mathrm{TiO}_{2}-\right.$ 700] also exhibits the lowest signal decay, which could be attributed to the same effect of limitation of charge recombination due to the presence of the $\mathrm{TiO}_{2}$ rutile phase. In addition, this material yields the highest signal that may be explained by the highest generation of charges due to the tail of absorption of rutile at that wavelength of excitation, as compared with $\mathrm{TiO}_{2} \mathrm{P} 25$ containing ca. $20 \%$ of rutile. Furthermore, the signal intensity is very close to that obtained under UV-A activation. This last explanation could also be considered for $\left[\mathrm{Au}_{10 \mathrm{~nm}} / \mathrm{TiO}_{2}\right]-700$. However, in this case the decay in electron mobility is higher, perhaps due to more efficient electron trapping onto larger Au NPs. It must be mentioned that $\mathrm{TiO}_{2} \mathrm{UV} 100$ also shows a small signal that can be associated with charge generation that might result from a defective $\mathrm{TiO}_{2}$ structure. $\mathrm{TiO}_{2} \mathrm{UV} 100$ is indeed not as well crystallized as $\mathrm{TiO}_{2} \mathrm{P} 25$, for example. Nevertheless, those charges rapidly recombine.

AtLSPR maximum excitation (or at $500 \mathrm{~nm}$ excitation in the absence of LSPR), and as for activation at $450 \mathrm{~nm}, \mathrm{Au}_{4 \mathrm{~nm}} /\left[\mathrm{TiO}_{2}-700\right]$ reveals the highest signal associated with the highest charge carrier generation (Fig. 14). In this case, it must be underlined that the signal intensity is only slightly reduced compared to excitation at $450 \mathrm{~nm}$. The other sample containing $\mathrm{TiO}_{2}$ calcined at $700{ }^{\circ} \mathrm{C}$, i.e. 


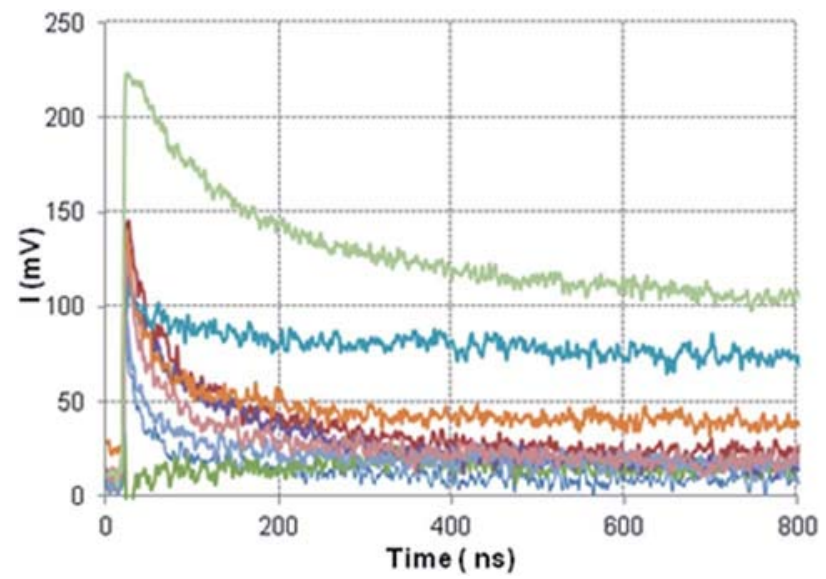

Fig. 13 TRMC signals at $450 \mathrm{~nm}$ on $\mathrm{TiO}_{2} \mathrm{UV} 100$ (pink), $\mathrm{TiO}_{2} \mathrm{P} 25$ (light green), $\mathrm{Au}_{3 \mathrm{~mm}} / \mathrm{TiO}_{2}$ (dark blue), $\left[\mathrm{Au}_{5 \mathrm{~nm}} / \mathrm{TiO}_{2}\right]-450$ (red), $\left[\mathrm{Au}_{10 \mathrm{~nm}} / \mathrm{TiO}_{2}\right]-700$ (dark green), $\mathrm{Au}_{3 \mathrm{~nm}} /\left[\mathrm{TiO}_{2}-450\right]$ (dark purple), $\mathrm{Au}_{4 \mathrm{~nm}} /\left[\mathrm{TiO}_{2}-700\right]$ (light blue), $\mathrm{Au}_{15 \mathrm{~nm}} / \mathrm{TiO}_{2}$ (orange) and $\mathrm{Au}_{50 \mathrm{~nm}} / \mathrm{TiO}_{2}$ (light purple).

$\left[\mathrm{Au}_{10 \mathrm{~nm}} / \mathrm{TiO}_{2}\right]-700$, also seems to generate charge carriers, however, to a lesser extent and with a rapid decrease of the signal, probably due to the higher electron trapping effect on larger Au NPs. It must be noticed here that $\mathrm{TiO}_{2} \mathrm{P} 25$ does not show any signal, meaning that absorption due to the presence of the rutile phase is no more effective at $500 \mathrm{~nm}$. From these observations, it may be assumed that LSPR effects may take place through the injection of hot electrons from the Au NPs to the conduction band of $\mathrm{TiO}_{2}$ nanoparticles. Additionally, the enhanced surface-normalized $\mathrm{CH}_{4}$ production rates observed over composites calcined at $700^{\circ} \mathrm{C}$ may thus be attributed to an increased charge carrier lifetime,

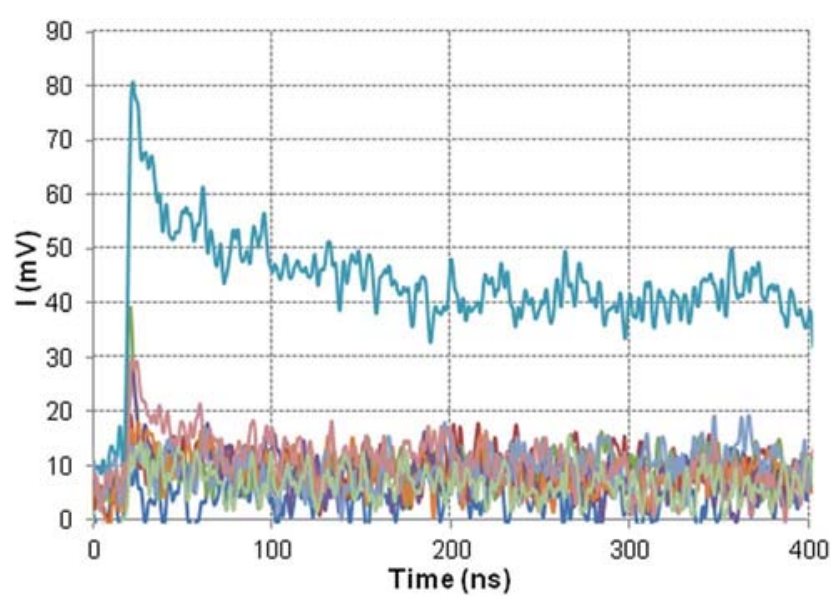

Fig. $14 \mathrm{TRMC}$ signals at $500 \mathrm{~nm}$ on $\mathrm{TiO}_{2} \mathrm{UV} 100$ (pink), $\mathrm{TiO}_{2} \mathrm{P} 25$ (light green), $\mathrm{Au}_{3 \mathrm{~nm}} / \mathrm{TiO}_{2}$ (dark blue), $\left[\mathrm{Au}_{5 \mathrm{~nm}} / \mathrm{TiO}_{2}\right]-450$ (red), $\left[\mathrm{Au}_{10 \mathrm{~nm}} / \mathrm{TiO}_{2}\right]-700$ (dark green), $\mathrm{Au}_{3 \mathrm{~nm}} /\left[\mathrm{TiO}_{2}-450\right]$ (dark purple), $\mathrm{Au}_{4 \mathrm{~nm}} /\left[\mathrm{TiO}_{2}-700\right]$ (light blue), $\mathrm{Au}_{15 \mathrm{~nm}} / \mathrm{TiO}_{2}$ (orange) and $\mathrm{Au}_{50 \mathrm{~nm}} / \mathrm{TiO}_{2}$ (light purple). 
which may be related to the peculiar oblong shape of the titania crystallites present in these materials (Fig. 7).$^{53}$ The peculiar shape of the SC may result from restructuration related to the anatase / rutile transition and is consistent with the speciftcity of $\mathrm{TiO}_{2}-700{ }^{\circ} \mathrm{C}$ towards Au NPdeposition and interaction (Fig. 5b). Finally, the absence of a signal for most of the composites further supports the limitation of the plasmon-based process by charge generation. It is expected that the resulting modest photocatalytic activities may be improved by increasing the gold content.

\section{Experimental}

Synthesis of photocatalysts

All photocatalysts were prepared through a well-known colloidal deposition method ${ }^{27,54-56}$ but without any protecting agent, using commercially available $100 \%$ anatase titania (Hombikat UV100 from Sachtleben Chemie GmbH, $384 \mathrm{~g}$ $\mathrm{m}^{-2}$ ). For all photocatalysts, a gold loading of $1 \mathrm{wt} \%$ was targeted. First, an aqueous solution of sodium borohydride $(0.1 \mathrm{M}, 2.54 \mathrm{~mL})$ was added to an aqueous solution of $\mathrm{HAuCl}_{4}(0.25 \mathrm{M}, 200 \mathrm{~mL})$, with $\mathrm{Au} / \mathrm{NaBH}_{4} 1 / 44: 5 \mathrm{~mol} \mathrm{~mol}^{-}{ }^{1}$. The yellow gold solution immediately turned dark red upon introduction of $\mathrm{NaBH}_{4}$, due to the formation of a gold sol, which is stabilized by the presence of $\mathrm{NaBH}_{4}$-derived molecules in electrostatic interaction with the Au NP. ${ }^{57}$ The support (1 g) was introduced directly a er the reduction step and the mixture was stirred for $30 \mathrm{~min}$ for total adsorption of the gold sol onto the support. A er ftltration and washing $\left(\mathrm{H}_{2} \mathrm{O} / 1 \mathrm{~L}\right)$, the pink powder was dried in air at $100{ }^{\circ} \mathrm{C}$ for $24 \mathrm{~h}$. The resulting $\mathrm{Au}_{3 \mathrm{~nm}} / \mathrm{TiO}_{2}$ product was calcined for $4 \mathrm{~h}$ in $\square$ owing air (100 mLmin ${ }^{-1}$ ) at different temperatures: $450^{\circ} \mathrm{C}, 700^{\circ} \mathrm{C}$ and $900^{\circ} \mathrm{C}$, yielding [Ausnm/ $\left.\mathrm{TiO}_{2}\right]-450,\left[\mathrm{Au}_{10 \mathrm{~nm}} / \mathrm{TiO}_{2}\right]-700$ and $\left[\mathrm{Au}_{43 \mathrm{~nm}} / \mathrm{TiO}_{2}\right]-900$, respectively.

A "pre-calcined"sample series was also prepared using the same method, with the $\mathrm{TiO}_{2}$ support previously calcined for $4 \mathrm{~h}$ in $\square$ owing air $\left(100 \mathrm{~mL} \mathrm{~min}^{-1}\right)$ at the same temperatures $\left(450^{\circ} \mathrm{C}, 700^{\circ} \mathrm{C}\right.$ and $\left.900^{\circ} \mathrm{C}\right)$. For these samples, the contact time between the $\mathrm{NaBH}_{4}$-stabilized gold sol and the support was extended in order to maximize adsorption of the gold sol on the lower surface area supports. The mixturewas thus stirred for $2 \mathrm{~h}, 48 \mathrm{~h}$ and $48 \mathrm{~h}$, when using $\mathrm{TiO}_{2}-450{ }^{\circ} \mathrm{C}, \mathrm{TiO}_{2}-$ $700{ }^{\circ} \mathrm{C}$ and $\mathrm{TiO}_{2}-900{ }^{\circ} \mathrm{C}$, respectively, yielding $\mathrm{Au}_{3 \mathrm{~nm}} /\left[\mathrm{TiO}_{2}-450\right], \mathrm{Au}_{4 \mathrm{~nm}} /\left[\mathrm{TiO}_{2}-700\right]$ and $\mathrm{Au}_{9 \mathrm{~nm}} /\left[\mathrm{TiO}_{2}-900\right]$, respectively. In the case of $\mathrm{TiO}_{2}-700^{\circ} \mathrm{C}$, deposition of the gold sol was subsequently tried for $96 \mathrm{~h}$ in order to increase the goldloading which appeared to be much lower $(0.49 \mathrm{wt} \%)$ than in all the other composites $(1.1$ T $0.2 \mathrm{wt} \%$ ). A new composite, yet still with a low gold loading of $0.74 \mathrm{wt} \%$, was obtained as Aunnm/[TiO $2-700]-2$.

Colloidal solutions of gold nanoparticles of $15 \mathrm{~nm}$ and $50 \mathrm{~nm}$ were purchased (nanoComposix, Econix, Au nanospheres, PVP) and directly deposited onto the uncalcined UV100 $\mathrm{TiO}_{2}$ support. The colloidal solution of gold $\left(5 \mathrm{mg} \mathrm{mL}^{-1}, 1 \mathrm{~mL}\right)$ and the support $(0.5 \mathrm{~g})$ were added to $100 \mathrm{~mL}$ of methanol (Carlo ERBA reagents S.A.S, 99.9\%) and stirred for $2 \mathrm{~h}$. A erfttration and washing $(\mathrm{MeOH} / 1 \mathrm{~L})$, the powderwas dried at $100^{\circ} \mathrm{C}$ for $24 \mathrm{~h}$. Two different sampleswere obtained:Au $15 \mathrm{~nm} /$ $\mathrm{TiO}_{2}$ and $\mathrm{Au} 50 \mathrm{~nm} / \mathrm{TiO}_{2}$.

Platinum-based materials were prepared by a similar colloidal deposition method, except reduction of the platinum salt was performed in the presence of the titania support. ${ }^{58}$ Titania ( $1 \mathrm{~g}$ ) was added to an aqueous solution of $\mathrm{H}_{2} \mathrm{PtCl}_{6}$ 
$(0.256 \mathrm{M}, 200 \mathrm{~mL})$ and stirred for $20 \mathrm{~min}$. Then, an aqueous solution of sodium borohydride $\left(0.1 \mathrm{M}, 2.54 \mathrm{~mL}, \mathrm{Pt} / \mathrm{NaBH}_{4} 1 / 41: 5 \mathrm{~mol} \mathrm{~mol}^{-1}\right)$ was added and the mixture was stirred for $30 \mathrm{~min}$. A erfttration and washing $\left(\mathrm{H}_{2} \mathrm{O} / 1 \mathrm{~L}\right)$, the grey powder was dried in air at $100{ }^{\circ} \mathrm{C}$ for $24 \mathrm{~h}$. Part of the resulting $\mathrm{Pt}_{3 \mathrm{~nm}} / \mathrm{TiO}_{2}$ composite was then calcined in $\square$ owing $\operatorname{air}\left(100 \mathrm{~mL} \mathrm{~min}^{-1}\right)$ for $4 \mathrm{~h}$ at $700^{\circ} \mathrm{C}$, yielding $\left[\mathrm{Pt}_{3 \mathrm{~nm}} / \mathrm{TiO}_{2}\right]-700$. All samples are summarised in Table 1.

\section{Characterization}

A Micromeritics Asap 2420 porosimeter was used to obtain Nitrogen adsorptiondesorption isotherms at $77 \mathrm{~K}$. Materials were outgassed at $250^{\circ} \mathrm{C}$ under primary vacuum for $4 \mathrm{~h}$ in order to desorb impurities from their surfaces and eliminate any water. Speciftc surface areas were calculated by the Brunauer, Emmett and Teller (BET) method in the relative pressure $\left(p / p_{0}\right)$ range $0.05-0.3$ and using t-plot methods.

X-ray diffraction (XRD) patterns were collected on a Bruker D8 Advance theta-theta diffractometer ( $\mathrm{Cu}$ Ka radiation, I $1 / 40.154 \mathrm{~nm}$ ), equipped with a LynxEye detector and operating at $40 \mathrm{kV}$ and $40 \mathrm{~mA}$. The datasets were acquired in step-scan mode over the $36-49^{\circ} 2 q$ range, using a step interval of $0.024^{\circ}$ and a counting time of $4 \mathrm{~s}$ per step. Powder samples were introduced in an alumina crucible, treated in situ at the desired temperature in $\square$ owing synthetic air using a heating chamber and cooled down to room temperature prior to data acquisition.

Transmission Electron Microscopy (TEM) was carried out on a JEOL 2100F microscope working at a $200 \mathrm{kV}$ accelerating voltage and equipped with a probe corrector for spherical aberrations, giving a point-to-point resolution of $0.18 \mathrm{~nm}$. The sample was dispersed in an ethanol solution for $2 \mathrm{~min}$. A drop of the solution was subsequently deposited on a copper grid covered with a holey carbon membrane for observation. Statistical M NP size distributions were obtained on brightfteld images using populations of more than 200 nanoparticles and ImageJ so ware. $^{59}$

UV-vis absorption spectra were recorded on a Perkin Elmer Lambda 950 Scan spectrophotometer equipped with a $100 \mathrm{~mm}$ diffuse re $\square$ ectance integrating sphere. UV-vis spectra were done on ftlms: powders were deposited on $2 \mathrm{~cm}$ diameter glass disks with the same surface concentration and using the same protocol as for the photocatalytic tests $\left(25 \mathrm{~g} \mathrm{~m}^{-2}\right)$.

Elemental analyses of the photocatalysts were performed using Inductively Coupled Plasma Atomic Emission Spectroscopy (ICP-AES). The limit ofdetection of the instrument is $0.1 \mathrm{mg} \mathrm{L}^{-1}$ for Au. Analysis of the gold component of the $\mathrm{Au} /$ $\mathrm{TiO}_{2}$ composites allowed us to calculate depositionyields which are deftned as the ratio between the actual deposited mass of Au (deduced from ICP-AES analysis) and the mass of $\mathrm{Au}$ introduced in the synthesis.

The charge carrier lifetimes in the $\mathrm{TiO}_{2}$-based composites were determined by microwave absorption experiments using the Time Resolved Microwave Conductivity method (TRMC) ${ }^{51,52}$ The TRMC technique is based on measurement of the change of microwave power re $\square$ ected by a sample, $D P(t)$, induced by its laser pulsed illumination. The relative difference $D P(t) / P$ can be correlated, for small perturbations of conductivity, to the difference of the conductivity $\mathrm{Ds}(t)$ considering the following equation: 


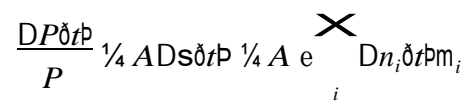

where $\mathrm{D} n_{i}(t)$ is the number of excess charge-carriers $i$ at time $t$ and $m_{i}$ is their mobility. The sensitivity factor $A$ is independent of time, but depends on different factors such as the microwave frequency or the dielectric constant. Considering that the trapped species have a small mobility, which can be neglected, $\mathrm{D} n_{i}$ is reduced to mobile electrons in the conduction band and holes in the valence band. And in the speciftc case of $\mathrm{TiO}_{2}$, the TRMC signal can be attributed to electrons because their mobility is much larger than that of the holes. ${ }^{51,52}$

The incident microwaves were generated by a Gunn diode of the $K_{a}$ band at 30 $\mathrm{GHz}$. The pulsed light source was an OPO laser (EKSPLA, NT342B) tunable from 225 to $2000 \mathrm{~nm}$. It delivers $8 \mathrm{~ns}$ fwhm pulses with a frequency of $10 \mathrm{~Hz}$. The light energy densities received by the sample were $0.8,1.5$ and $1.4-2.2 \mathrm{~mJ} \mathrm{~cm}^{-2}$ at $360 \mathrm{~nm}, 450 \mathrm{~nm}$ and at the LSPR maximum (500 $\mathrm{nm}$ by default), respectively.

\section{Photocatalytic tests}

The photocatalytic set-up is composed of four main parts. (1) Generation of the reaction mixture was carried out by bubbling $\mathrm{CO}_{2}$ (Air Product, 99.5\%) through a thermo-controlled water saturator maintained at $35^{\circ} \mathrm{C}$ (absolute humidity $1 / 4$ $4.3 \%$ ) at $0.3 \mathrm{mLmin}^{-1}$. (2) The continuously $\square$ owing reaction mixture $\left(\mathrm{CO}_{2}+\mathrm{H}_{2} \mathrm{O}\right)$ $\square$ ow passes through a light-transparent photoreactor $(6 \mathrm{~mL})$ equipped with a $\mathrm{Hg}$ lamp top-irradiation system, simulating artiftcial solar light with light concentrator (150 W Ceramic-Metal-Halide Hg Lamp). The irradiance was $46 \mathrm{~W} \mathrm{~m}^{-2}$ for wavelengths between 300 and $400 \mathrm{~nm}$ and $5100 \mathrm{~W} \mathrm{~m}^{-2}$ for the whole lamp spectrum. The irradiated surface into the photoreactor is $18.8 \mathrm{~cm}^{2}$. (3) Ventilators were ftxed on the photoreactor to minimize temperature increase during photocatalytic tests. The maximum temperature of the reactor was about $40^{\circ} \mathrm{C}$ during test. (4) Finally, products from the reactor were analysed online using a micro-GC analytical system (Agilent 3000A SRA instrument).

To perform photocatalytic tests, $50 \mathrm{mg}$ of materials were homogeneously suspended in ethanol and slowly deposited on a $50 \mathrm{~mm}$ diameter glass disk until dry and further thermally treated at $100^{\circ} \mathrm{C}$ for $2 \mathrm{~h}$. The surface concentration of the photocatalyst on the glass disc was $25 \mathrm{~g} \mathrm{~m}^{-2}$. The glass disk was then inserted into the photoreactor and the set-up was purged for $5 \mathrm{~min}$ with a high $\mathrm{CO}_{2} \square$ ow $\left(>100 \mathrm{~mL} \mathrm{~min}^{-1}\right)$ to remove air and other gas impurities. Before starting the test, the set-up was run with a $\mathrm{CO}_{2}$ gas $\square$ ow $\left(0.3 \mathrm{~mL} \mathrm{~min}^{-1}\right)$ without illumination to achieve dark absorption equilibrium. Finally, the lamp was switched on. The standard duration of a photocatalytic test was $10 \mathrm{~h}$.

Production rates were calculated according to these equations:

$$
\begin{gathered}
r \cdot \mathrm{mol} \mathrm{h}^{-1} \mathrm{~g}^{-1} \Sigma_{1 / 4} \frac{1 / \mathrm{X}] \times 10^{-6} \times \text { fflow rateP } \times 60}{V \times m_{\text {photocat }}} \\
r \quad \mathrm{~mol} \mathrm{~h}^{-1} \mathrm{~m}_{\text {irradiated }}{ }^{-2_{1}} \frac{1 / \mathrm{X}] \times 10^{-6} \times \partial \text { flow rateP } \times 60}{V \times S_{\text {irradiated }}}
\end{gathered}
$$


where $[\mathrm{X}]$ is the concentration of $\mathrm{CH}_{4}$ or $\mathrm{H}_{2}$ in ppm, $m_{\text {photocat }}$ is the mass of photocatalyst, $S_{\text {irradiated }}$ is the irradiated surface $\left(0.001885 \mathrm{~m}^{2}\right)$, the $\square$ ow rate is $0.0003 \mathrm{~L} \mathrm{~min}^{-1}$ and $V_{\mathrm{m}} 1 / 424.79 \mathrm{~L} \mathrm{~mol}^{-1}$ (STP conditions).

Selectivity was calculated using these equations:

$$
\begin{aligned}
& \mathrm{CH}_{4} \text { selectivity } \frac{1 / 4}{8 \times r_{\mathrm{CH}_{4}} \mathrm{p} 2 \times r_{\mathrm{H}_{2}}} \\
& \mathrm{H}_{2} \text { selectivity } 1 / 41-\left[\mathrm{CH}_{4} \text { selectivity }\right]
\end{aligned}
$$

The production rate per speciftc surface area of material ( $r x / B E T)$ was calculated by dividing the production rate per gram by the BET speciftc surface area of each compound.

Internal quantum yields $\mathrm{h}$ were calculated by this formula:

$$
\mathrm{h} 1 / 4 \frac{8 \times r_{\mathrm{CH}_{4}} \mathrm{p} 2 \times r_{\mathrm{H}_{2}}}{\mathbf{f}_{\text {absorbed photons }}} \frac{n_{\mathrm{e}}}{=}=
$$

where $\mathbf{f}_{\text {absorbed photons }}$ is the absorbed photon $\square$ ux determined by UV-vis absorbance measurements.

\section{Conclusions}

By evaluating the solar and visible photocatalytic activities of a series of goldtitania nanocomposites for the reduction of carbon dioxide with water, we have shown the contribution of a plasmon-based process, in addition to the directUVinduced SC-based process, in the overall solar transformation. Comparison with Pt composites and bare titania SCs suggests that the visible activity, induced by gold nanoparticles only, relies on the generation of hot carriers in the M NPs. Such a hot electron-mediated process may account for up to $20 \%$ of the overall solar activity in highly crystallized composites. It is more efficient over larger Au NPs (50 nm). One major speciftcity of the gold-mediated visible transformation is the $100 \%$ selectivity towards methane, i.e. the preferential reduction of $\mathrm{CO}_{2}$ over $\mathrm{H}_{2} \mathrm{O}$. Dehydroxylation of titania is crucial to achieve such total selectivity.

\section{Conflicts of interest}

There are no con $\square$ icts to declare.

\section{Acknowledgements}

Financial support from IFPEN is gratefully acknowledged. The authors also wish to thank Dris Ihiawakrim (IPCMS, CNRS UMR 7504) for performing TEM analyses. ZC and CCJ gratefully acknowledge the ftnancial support of the Agence Nationale de la Recherche (ANR) through the UpPhotoCat project. 


\section{Notes and references}

1 W.-N. Wang, J. Soulis, Y. J. Yang and P. Biswas, Aerosol Air Qual. Res., 2014, 14, 533.

2 S. N. Habisreutinger, L. Schmidt-Mende and J. K. Stolarczyk, Angew. Chem., Int. Ed., 2013, 52, 7372 .

3 J. K. Stolarczyk, S. Bhattacharyya, L. Polavarapu and J. Feldmann, ACS Catal., 2018, 8, 3602.

4 S. Neaţu, J. A. Maciá-Agulló, P. Concepciōn and H. Garcia, J. Am. Chem. Soc., 2014, 136, 15969.

5 Q.Zhai, S. Xie, W. Fan, Q.Zhang, Y. Wang, W. Deng and Y. Wang, Angew. Chem., Int. Ed., 2013, 52, 5776.

6 J. Ran, M. Jaroniec and S.-Z. Qiao, Adv. Mater., 2018, 30, 1704649.

7 F. Zaera, Top. Catal., 2018, 61, 336.

8 A. Manjavacas, J. G. Liu, V. Kulkarni and P. Nordlander, ACS Nano, 2014, 8, 7630.

9 S. C. Warren and E. Thimsen, Energy Environ. Sci., 2012, 5, 5133.

10 Y.Zhang, S. He, W. Guo, Y. Hu, J. Huang, J. R. Mulcahy and W. D. Wei, Chem. Rev., 2018, 118, 2927.

11 M. L. Brongersma, N. J. Halas and P. Nordlander, Nat. Nanotechnol., 2015, 10, 25.

12 G. V. Hartland, L. V. Besteiro, P. Johns and A. O. Govorov, ACS Energy Lett., 2017, 2, 1641.

13 P. Christopher and M. Moskovits, Annu. Rev. Phys. Chem., 2017, 68, 379.

14 Y. Shiraishi, N. Yasumoto, J. Imai, H. Sakamoto, S. Tanaka, S. Ichikawa, B. Ohtani and T. Hirai, Nanoscale, 2017, 9, 8349.

15 S. Mukherjee, L. Zhou, A. M. Goodman, N. Large, C. Ayala-Orozco, Y. Zhang, P. Nordlander and N. J. Halas, J. Am. Chem. Soc., 2014, 136, 64.

16 X.-C. Ma, Y. Dai, L. Yu and B.-B. Huang, Light: Sci. Appl., 2016, 5, e16017.

17 K. Wu, J. Chen, J. R. McBride and T. Lian, Science, 2015, 349, 632.

18 M. J. Kale and P. Christopher, Science, 2015, 349, 587.

19 V. Caps, S. Arrii, F. Morftn, G. Bergeret and J.-L. Rousset, Faraday Discuss., 2008, 138, 241.

20 I. Ro, J. Resasco and P. Christopher, ACS Catal., 2018, 8, 7368.

21 C. Marchal, T. Cottineau, C. Colbeau-Justin, V. Caps and V. Keller, Adv. Energy Mater., 2018, 8, 1702142.

22 E. Karamian and S. Sharifnia, J. CO2 Util., 2016, 16, 194.

23 S. Bai, N. Zhang, C. Gao and Y. Xiong, Nano Energy, 2018, 53, 296.

24 Z. Xiong, Z. Lei, Y. Li, L. Dong, Y. Zhao and J. Zhang, J. Photochem. Photobiol., $C, 2018,36,24$

25 Y. Ji and Y. Luo, J. Am. Chem. Soc., 2016, 138, 15896.

26 L. Liu, H. Zhao, J. M. Andino and Y. Li, ACS Catal., 2012, 2, 1817.

27 P. Lignier, M. Comotti, F. Schüth, J.-L. Rousset and V. Caps, Catal. Today, 2009, $141,355$.

28 O.K.Varghese, M.Paulose,T.J.LaTempaand C.A. Grimes, NanoLett., 2009, 9, 731.

29 M.Zhang, Z.Jin, Z.Zhangand H. Dang, Appl. Surf. Sci., 2005, 250, 29; Q. Li, K. Wang, S. Zhang, M. Zhang, J. Yang and Z. Jin, J. Mol. Catal. A: Chem., 2006, 258, 83. 
30 W. Gao, S. Sivaramakrishnan, J. Wen and J.-M. Zuo, Nano Lett., 2015, 15, 2548.

31 R. Van Hardeveld and F. Hartog, Surf. Sci., 1969, 15, 189.

32 M. Pelaez, N. T. Nolan, S. C. Pillai, M. K. Seery, P. Falaras, A. G. Kontos, P. S. M. Dunlop, J. W. J. Hamilton, J. A. Byrne, K. O'shea, M. H. Entezari and D. D. Dionysiou, Appl. Catal., B, 2012, 125, 331.

33 K. M. Schindler and M. Kunst, J. Phys. Chem., 1990, 94, 8222.

34 P. Akhter, M. Hussain, G. Saracco and N. Russo, Fuel, 2015, 149, 55.

35 M. Murdoch, G. I. N. Waterhouse, M. A. Nadeem, J. B. Metson, M. A. Keane, R. F. Howe, J. Llorca and H. Idriss, Nat. Chem., 2011, 3, 489.

36 C. Marchal, M.Behr, F. Vigneron, V.Capsand V. Keller, NewJ. Chem., 2016, 40, 4428.

37 C. Marchal, A. Piquet, M. Behr, T. Cottineau, V. Papae himiou, V. Keller and V. Caps, J. Catal., 2017, 352, 22.

38 V. Mendez, V. Caps and S. Daniele, Chem. Commun., 2009, 3116.

39 A. Fkiri, A. Mezni, C. Robert, V. Caps and L. S. Smiri, Colloids Surf., A, 2017, $530,85$.

40 S. Mukherjee, F. Libisch, N. Large, O. Neumann, L. V. Brown, J. Cheng, J. B. Lassiter, E. A. Carter, P. Nordlander and N. J. Halas, Nano Lett., 2013, $13,240$.

41 U. Aslam, V. G. Rao, S. Chavez and S. Linic, Nat. Catal., 2018, 1, 656.

42 Y. Tian and T. Tatsuma, J. Am. Chem. Soc., 2005, 127, 7632.

43 G. Ganguly, M. Sultana and A. Paul, J. Phys. Chem. C, 2017, 121, 15326.

44 H. Zhang, S. Kawamura, M. Tamba, T. Kojima, M. Yoshiba and Y. Izumi, J. Catal., 2017, 352, 452.

45 R. Wang, K. Hashimoto, A. Fujishima, M. Chikuni, E. Kojima, A. Kitamura, M. Shimohigoshi and T. Watanabe, Nature, 1997, 388, 431.

46 H.-Y. T. Chen, S. Tosoni and G. Pacchioni, ACS Catal., 2015, 5, 5486.

47 X. Zhang, X. Li, D. Zhang, N. Q. Su, W. Yang, H. O. Everitt and J. Liu, Nat. Commun., 2017, 8, 14542.

48 J. S. DuChene, B. C. Sweeny, A. C. Johnston-Peck, D. Su, E. A. Stach and W. D. Wei, Angew. Chem., Int. Ed., 2014, 126, 8021.

49 K. Qian, B. C. Sweeny, A. C. Johnston-Peck, W. Niu, J. O. Graham, J. S. DuChene, J. Qiu, Y.-C. Wang, M. H. Engelhard, D. Su, E. A. Stach and W. D. Wei, J. Am. Chem. Soc., 2014, 136, 9842.

50 X.-T. Kong, Z. Wang and A. O. Govorov, Adv. Opt. Mater., 2017, 5, 1600594.

51 O.A. Tahiri Alaoui, C. Herissan, M. E. LeQuoc, M.Zekri, S. Sorgues, H. Remita and C. Colbeau-Justin, J. Photochem. Photobiol., A, 2012, 242, 34.

52 C. Colbeau-Justin, M. Kunst and D. Huguenin, J. Mater. Sci., 2003, 38, 24.

53 Y.Ohsaki, N. Masaki, T. Kitamura, Y. Wada, T. Okamoto, T. Sekino, K. Niihara and S. Yanagida, Phys. Chem. Chem. Phys., 2005, 7, 4157.

54 S. Mishra, V.Mendez, E.Jeanneau, V. Capsand S. Daniele, Eur.J.Inorg. Chem., 2013, 500.

55 V. Mendez, K. Guillois, S. Daniele, A. Tuel and V. Caps, Dalton Trans., 2010, 39, 8457.

56 S. Biella, F. Porta, L. Prati and M. Rossi, Catal. Lett., 2003, 90, 1.

57 C. Deraedt, L. Salmon, S. Gatard, R. Ciganda, R. Hernandez, J. Ruiz and D. Astruc, Chem. Commun., 2014, 50, 14194.

58 K. Guillois, L. Burel, A. Tuel and V. Caps, Appl. Catal., A, 2012, 415-416, 1.

59 W. Rasband, http://rsb.info.nih.gov/ij/. 